\title{
Neuropeptide Y-Mediated Long-Term Depression of Excitatory Activity in Suprachiasmatic Nucleus Neurons
}

\author{
Anthony N. van den Pol, ${ }^{1,2}$ Karl Obrietan, ${ }^{2}$ Gong Chen, ${ }^{1}$ and Andrei B. Belousov ${ }^{2}$ \\ ${ }^{1}$ Section of Neurosurgery, Yale University School of Medicine, New Haven, Connecticut 06520, and ${ }^{2}$ Department of \\ Biological Sciences, Stanford University, Stanford, California 94305
}

\begin{abstract}
A brief exposure to light can shift the phase of mammalian circadian rhythms by $1 \mathrm{hr}$ or more. Neuropeptide $\mathrm{Y}$ (NPY) administration to the hypothalamic suprachiasmatic nucleus, the circadian clock in the brain, also causes a phase shift in circadian rhythms. After a phase shift, the neural clock responds differently to light, suggesting that learning has occurred in neural circuits related to clock function. Thus, certain stimuli can produce effects that last for an extended period, but possible mechanisms of this long-term effect have not been previously examined at the cellular level. Here, we report that NPY caused a long-term depression in both electrical activity and intracellular calcium levels of neurons, as studied with whole-cell patch-clamp recording and Fura-2 digital imaging. In contrast to the immediate $(1 \mathrm{sec})$ recovery after relief from glutamate receptor blockade, a brief single application of NPY
\end{abstract}

(100 nm) depressed cytosolic $\mathrm{Ca}^{2+}$ for $>1 \mathrm{hr}$. The mechanism of this long-term calcium depression, a form of cellular learning, is dependent on the simultaneous release of glutamate and activation of NPY receptors, because both the extended response to NPY and any aftereffect were blocked by coapplication of glutamate receptor antagonists. Postsynaptic actions of NPY, mediated by both Y1- and Y2-like receptors, were short term and recovered rapidly. The primary site of long-term NPY actions may be on presynaptic glutamatergic axons, because the frequency of miniature excitatory postsynaptic currents in the presence of tetrodotoxin was reduced by transient exposure to NPY in both cultures and slices.

Key words: suprachiasmatic nucleus; mammalian circadian clock; glutamate; NPY; LTD; learning biological clock; phaseshift; neuroendocrine; hypothalamus
In the absence of environmental cues, the brain's circadian clock in the suprachiasmatic nucleus ( $\mathrm{SCN}$ ) generates a daily rhythm that is remarkably accurate in its timing (for review, see van den Pol and Dudek, 1993). The phase of this rhythm can be shifted by photic stimulation of the retina via glutamatergic pathways that project directly to the SCN (Meijer et al., 1988; Cahill and Menaker, 1989; Colwell et al., 1991; Kim and Dudek, 1991) or to the intergeniculate leaflet (IGL) and then to the SCN (Harrington et al., 1985; Card and Moore, 1989). Stimulation or damage to the neuropeptide Y (NPY)containing cells of the IGL or direct stimulation of the SCN with NPY causes a significant phase shift of circadian rhythms (Harrington and Rusak, 1986; Johnson et al., 1989; Rusak et al., 1989), as does altering glutamate transmission to the SCN (Meijer et al., 1988; Colwell et al., 1991).

Neurons of the circadian clock respond to light differently depending on the phase of the circadian clock. A pulse of light at one part of the circadian cycle will advance the phase, whereas a similar pulse at a different part of the cycle will delay the phase (Meijer et al., 1988; Nelson and Takahashi, 1991). Furthermore, photic stimulation at certain times of day alters the response of the clock neurons to photic stimulation at later times in the same $24 \mathrm{hr}$ period. This change in the response to light can be considered a novel form of learning and is consistent with Thompson's

Received May 9, 1996; revised June 21, 1996; accepted June 25, 1996.

This research was supported by National Institutes of Health Grants NS 34887 and NS 10174, the National Science Foundation, and the Air Force Office of Scientific Research. We thank Dr. Fred Sigworth and Dr. Craig Heller for helpful suggestions. Correspondence should be addressed to Anthony N. van den Pol, Section of Neurosurgery, Yale University School of Medicine, 333 Cedar Street, New Haven, CT 06520.

Copyright (C) 1996 Society for Neuroscience $0270-6474 / 96 / 165883-13 \$ 05.00 / 0$
(1967) definition of learning as a response modification resulting from experience.

A single pulse of light (Nelson and Takahashi, 1991) or a single application of NPY (Albers and Ferris, 1984; Medanic and Gillette, 1993; Huhman and Albers, 1994) can generate a phase shift of $1 \mathrm{hr}$ or more, suggesting a change in neuronal behavior may occur during this period. This hypothetically could be achieved by a temporally extended change in neuronal activity, followed by its resumption at a new phase. Because brief application of NPY produces dramatic and long-term shifts in clock-regulated physiology and behavior, we studied the ability of NPY, found in a high density of axons innervating the SCN (Chronwall et al., 1985) to induce long-term changes in neuronal $\mathrm{Ca}^{2+}$ levels and electrical activity by a mechanism involving modulation of glutamate neurotransmission. Because NPY also may exert long-lasting effects on hypothalamic regulation of food intake (Stanley and Leibowitz, 1985) and endocrine secretion (McDonald et al., 1985, 1989) via a similar mechanism, we also studied medial hypothalamic neurons in parallel experiments.

NPY, one of the most widespread neuroactive peptides in the brain, can act at several different $\mathrm{Y}$ receptors, of which Y1 and Y2 are the most completely characterized. In other regions of the brain, such as the CA1 region of the hippocampus where NPY has been extensively studied, the majority of effects are mediated through presynaptic Y2-like receptors (Colmers et al., 1991; Bleakman et al., 1993). Using selective agonists, we found that hypothalamic neurons were quite different from hippocampal pyramidal neurons in the subcellular location and type of receptors that mediated NPY effects. Some of our data have been presented in abstract form (van den Pol et al., 1995a). 


\section{MATERIALS AND METHODS}

Whole-cell patch-clamp recordings: culture. Whole-cell recordings were made with an Axoclamp-2B amplifier and a List EPC-7 amplifier. Glass pipettes were filled with (in $\mathrm{mM}$ ): 145 potassium methyl sulfate, 10 HEPES, $5 \mathrm{MgCl}_{2}$, 1.1 EGTA, 4 Na-ATP, 0.5 Na-GTP, pH 7.2, 310 mOsm. In most cases, neither negative nor positive current was applied to the cells during current-clamp recording. Cells were recorded in an external solution containing (in mM): $158.5 \mathrm{NaCl}, 2.5 \mathrm{KCl}, 2 \mathrm{CaCl}_{2}, 10$ HEPES, $1 \times 10^{-3}$ glycine, and 10 glucose, $\mathrm{pH} 7.3,325 \mathrm{mOsm}$. Glutamate receptor block contained D,L-2-amino-5-phosphonovalerate (AP-5) $(100 \mu \mathrm{M})$ and 6-cyano-7-nitroquinoxaline (CNQX) $(10 \mu \mathrm{M})$. A multibarrel flow-pipe perfusion system was used to stimulate the cells. Neurons were continuously perfused $(2 \mathrm{ml} / \mathrm{min})$ in a chamber with $1 \mathrm{ml}$ volume. The flow of AP-5/CNQX solution was stopped during the application period of both control buffer and buffer containing NPY. Agonists could be applied or completely washed away from the recorded neuron in 1-2 sec with flow-pipe application. Only one cell was recorded from each coverslip. Recordings were done at $20-22^{\circ} \mathrm{C}$. Cytosine arabinofuranoside and glutamate were from Sigma (St. Louis, MO); AP-5, CNQX, $t$-aminocyclopentane-1,3-dicarboxylic acid (t-ACPD), $\omega$-conotoxinGVIA, bicuculline methiodide, and TTX from Research Biochemicals (Natick, MA); Fura-2 AM ester, Fura-2 acid, and $\mathrm{Ca}^{2+}$ standards from Molecular Probes (Eugene, OR); papain from Worthington Biochemicals (Freehold, NJ); NPY agonists from Sigma, Peninsula (Hubbell, MI), and gift of Dr. L. Cornfield.

Whole-cell patch-clamp recordings: slice. Sprague Dawley rats (4 weeks old) were used to prepare SCN slices. After decapitation under full halothane anesthesia, the brain was removed rapidly and placed in ice-cold, aerated buffer (described below). The hypothalamus was dissected out, and $400-\mu \mathrm{m}$-thick coronal SCN slices were cut with a vibroslicer (Technical Products International).

After preparation, the slices were kept in artificial CSF (ACSF) at room temperature for at least $1 \mathrm{hr}$ before using. ACSF contained (in $\mathrm{mm}$ ): $124 \mathrm{NaCl}, 3.0 \mathrm{KCl}, 2.0 \mathrm{CaCl}_{2}, 2.0 \mathrm{MgCl}_{2}, 1.23 \mathrm{NaH}_{2} \mathrm{PO}_{4}, 26$ $\mathrm{NaHCO}_{3}$, and 10 glucose, continuously aerated with $95 \% \mathrm{O}_{2} / 5 \% \mathrm{CO}_{2}$, $\mathrm{pH}$ kept at 7.4. A slice then was adhered to a piece of lens paper and transferred to the experimental interface chamber with constant flow of the oxygenated medium $(4 \mathrm{ml} / \mathrm{min})$. Glass pipettes pulled from borosilicate glass capillaries of $2 \mathrm{~mm}$ diameter and $0.2 \mathrm{~mm}$ wall thickness were filled with an internal solution containing (in mM): 145 potassium methyl sulfate, $2 \mathrm{MgCl}_{2}, 0.1 \mathrm{CaCl}_{2}, 1.1$ EGTA, 10 HEPES, 2 Na-ATP, 0.3 Na-GTP, pH 7.2, 290 mOsm. After filling, the patch electrodes had resistances of 5-7 M $\Omega$. They were inserted into the SCN during observation through a stereomicroscope. With positive pressure applied to the recording pipette to eject a small fluid stream, the recording pipette was advanced into the brain slices until a partial seal was obtained. Whole-cell access then was obtained by applying negative pressure to the pipette. The recordings were made at room temperature $\left(20-22^{\circ} \mathrm{C}\right)$. Bicuculline $(50 \mu \mathrm{M})$ was added to the ACSF to block $\mathrm{GABA}_{\mathrm{A}}$-mediated neurotransmission. To stimulate excitatory axons projecting to the SCN, bipolar electrodes were placed at the optic nerve. Both retinal and nonretinal axons were stimulated. The electrical impulses $(0.2 \mathrm{msec}, 0.5 \mathrm{~Hz})$ were delivered through an isolation unit from a Grass 44 stimulator. The stimulating current was 50-400 $\mu \mathrm{A}$. Drugs were delivered by bath application in the slice chamber. Complete bath exchange took 90-120 sec.

Cultures. Cells were cultured from Sprague Dawley rats on embryonic days 18-21 (E18-E21). Cultures were made either from the 500- $\mu \mathrm{m}$ diameter punches of the SCN area or were made from a more extensive area that included the medial hypothalamus. Tissue was enzymatically treated (Obrietan and van den Pol, 1995; van den Pol et al., 1995b), and plated onto poly-lysine-treated glass coverslips. Cultures were maintained in glutamate and glutamine-free DMEM (Life Technologies, Gaithersburg, MD) with $10 \%$ fetal bovine serum, $100 \mathrm{U} / \mathrm{ml}$ penicillin/streptomycin, $6 \mathrm{gm} / 1$ glucose, and cytosine arabinofuranoside $(1 \mu \mathrm{M})$. Cells were kept in a Napco incubator at $37^{\circ} \mathrm{C}$ and $5 \% \mathrm{CO}_{2}$ for $20-41 \mathrm{~d}$ before use. CNQX $(10 \mu \mathrm{M})$ and AP-5 $(100 \mu \mathrm{M})$ were added to the tissue culture medium 4-7 d after the initial plating to inhibit glutamate-mediated excitotoxicity.

Fura-2 $\mathrm{Ca}^{2+}$ digital imaging. During long periods of whole-cell electrical recording, cells may be dialyzed through the recording pipette. Digital imaging eliminates the potential damage to the cell membrane during patch-clamp recording that may interfere with long-term experiments. Cells were loaded with Fura-2 AM $(5 \mu \mathrm{M})$ and studied in a perfusion solution containing (in $\mathrm{mM}$ ): $137 \mathrm{NaCl}, 25$ glucose, $10 \mathrm{HEPES}, 5 \mathrm{KCl}, 3$ $\mathrm{CaCl}_{2}, 1 \times 10^{-3}$ glycine, $\mathrm{pH}$ 7.4. The coverslip was held in a laminar flow,
$180 \mu \mathrm{l}$ perfusion chamber (Forscher et al., 1987) that allowed the rapid (5 sec) and complete change in solutions. Cells were imaged on a Nikon Diaphot 300 inverted microscope with an Olympus DApo $40 \times$ objective with high UV light transmittance. Sequential switching between 340/380 $\mathrm{nm}$ excitation filters was performed by a Sutter filter wheel. Emitted light was first passed through a $480 \mathrm{~nm}$ filter and then directed at a Hamamatsu 2400 silicon-intensified target video camera. Excitation light from a $150 \mathrm{~W}$ xenon lamp was attenuated by $90 \%$ using neutral density filters to allow for continuous recording over long durations without significant photobleaching or phototoxicity. Data were collected every 2 $\mathrm{sec}$ in short experiments and every $10 \mathrm{sec}$ in long experiments. Video background was subtracted, and ratiometric data calculated. In some of the figures, several neurons recorded from the same video field are depicted, allowing analysis of temporal and amplitude variability in response to different NPY agonists. Most experiments were performed in at least 3 cultures, and some used up to 14 cultures. Peripheral devices were controlled by a 486 computer using Fluor software (Universal Imaging, West Chester, PA). $\mathrm{Ca}^{2+}$ calibrations were performed with $\mathrm{Ca}^{2+}$ standards and Fura-2 acid (Grynkiewicz et al., 1985).

\section{RESULTS}

\section{Electrical activity: slice}

Whole-cell recordings were made from the $\mathrm{SCN}$ in coronal slices. Of 51 cells recorded, 8 showed good $\mathrm{Na}^{+}$and $\mathrm{K}^{+}$currents, generated action potentials, and maintained a stable resting membrane potential of $58 \mathrm{mV} \pm 3.1 \mathrm{mV}(\mathrm{SD})$. Electrical stimulation of glutamatergic axons innervating the SCN evoked stable EPSPs in SCN neurons that could be blocked with the glutamate receptor antagonists AP-5 $(100 \mu \mathrm{M})$ and CNQX $(10 \mu \mathrm{M})$ (Fig. 1C). NPY $(500 \mathrm{nM})$ added to the bath for 8 min caused a substantial decrease in the amplitude of the evoked EPSP (Fig. $1 A, B$ ). When the time integral of the EPSP (Fig. $1 B$ ) (time $\times \Delta \mathrm{V}$ ) was compared, NPY evoked a large decrease $(>60 \%)$. When NPY was washed out, the EPSP amplitude remained depressed for long recording periods $>90 \mathrm{~min}$. During that time, the amplitude slowly returned toward its pre-NPY level, but did not reach it.

These data from SCN slices suggested NPY exerted long-term depressing actions on glutamate-mediated EPSPs. Because the long duration of the effect could be attributable to the slow washout of NPY, a potentially sticky peptide, from the slice, we turned to monolayer tissue culture in which complete washout can be more quickly and effectively achieved. Experiments below were performed on cultured neurons, except for the series of experiments on the presynaptic site of action, which were performed on neurons both in slice and in culture.

\section{Electrical activity: culture}

With whole-cell recording of cultured neurons, we found that NPY (100 nM-1 $\mu \mathrm{M})$ caused a depression in the frequency of EPSPs and in the membrane potential of 13 of 15 cultured neurons (Fig. $2 A, D, F$ ). In 10 current-clamped neurons recorded for at least 40-50 min, a 2 min exposure to NPY (100 nM-1 $\mu \mathrm{M})$ caused a hyperpolarization of -5 to $-23 \mathrm{mV}$ that had not returned to baseline membrane potential even by $30 \mathrm{~min}$ after NPY washout (Fig. $2 A, D, G, H$ ). Of the 13 neurons that responded to NPY, the mean spike frequency was reduced from a pre-NPY level of $2.1 \pm 0.4$ to $0.4 \pm 0.1 \mathrm{~Hz}$ during NPY treatment, and the $I-V$ relationship was shifted (Fig. $2 F$ ). Five minutes after complete NPY washout, spike frequency still was depressed to $0.7 \pm 0.1 \mathrm{~Hz}$ $(p<0.01)$. EPSPs were reduced in amplitude by NPY. After NPY washout, the hyperpolarized membrane potential continued to recover to a more depolarized potential, and the spike frequency also showed continued recovery with an increase in spikes. That neurons continued to show recovery during the time course of the experiments suggests that the long-duration depression exerted by 

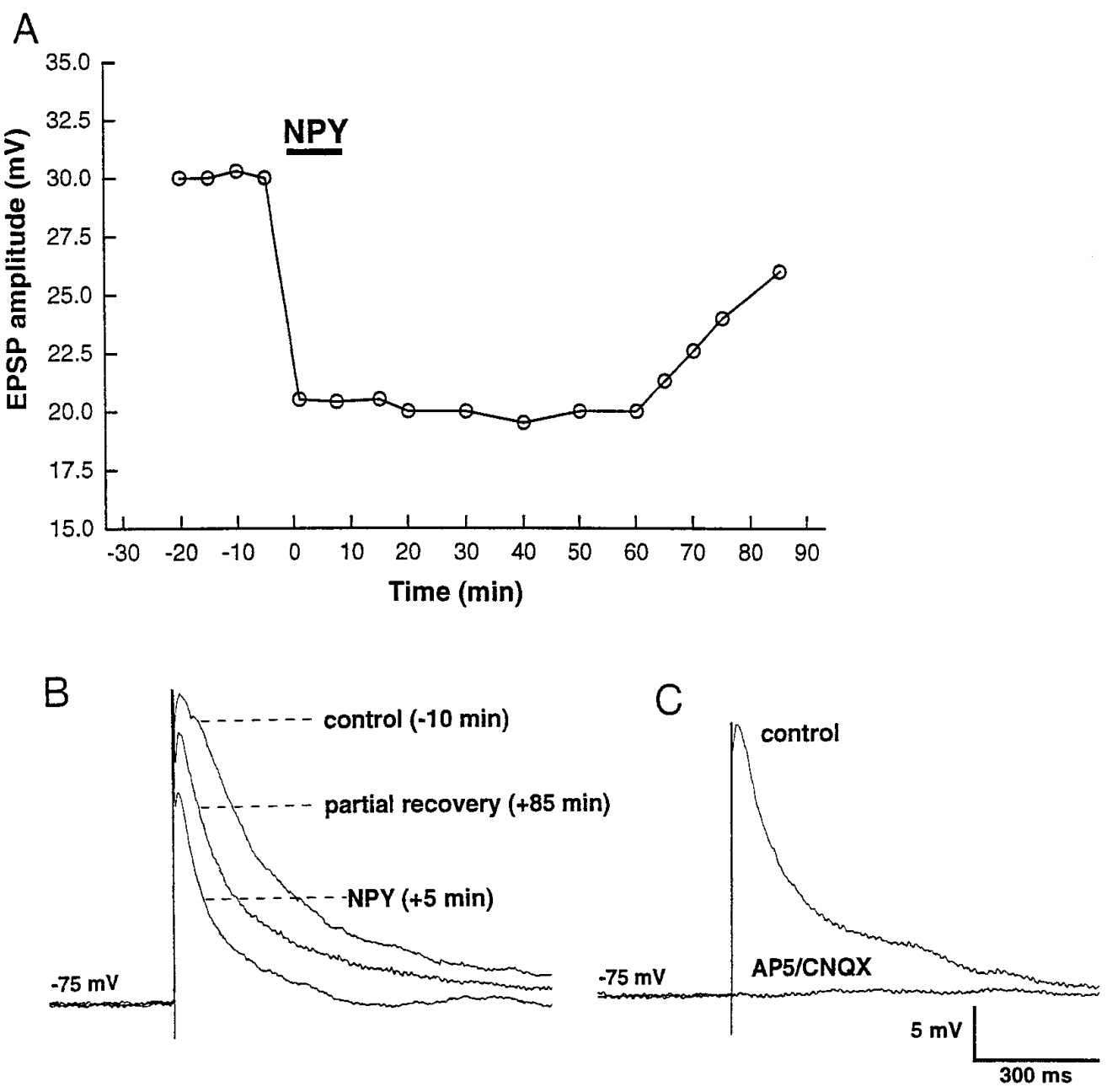

Figure 1. Whole-cell patch-clamp recording: slice. $A$, Evoked EPSP amplitude was decreased substantially by NPY in the bath solution. The amplitude remained depressed for $\sim 1.5 \mathrm{hr}$ after NPY introduction and had not fully returned to normal by the end of the trace shown. At the end of the experiment, the amplitude showed a second decrease; because this second decrease (after $90 \mathrm{~min}$ ) (data not shown) was accompanied by an increase in access resistance $(+50 \%)$, we only show the time when access resistance was stable, between 12 and $15 \mathrm{M} \Omega$. Access resistance was determined from voltage pulses at different stages of the recording. $B$, Representative traces from the neuron shown in $A$. Control (pre-NPY) EPSP is shown $(-10 \mathrm{~min})$, together with $5 \mathrm{~min}$ after NPY introduction, and $85 \mathrm{~min}$ after NPY introduction (75 min after NPY washout). $C$, AP-5 $(100 \mu \mathrm{M})$ and CNQX $(10 \mu \mathrm{M})$ completely blocked the evoked EPSP. Before NPY exposure, the input resistance was $450 \mathrm{M} \Omega$. In the period after NPY exposure, the input resistance decreased by $10 \%$ and remained within $10 \%$ of the pre-NPY input resistance for the entire experiment.
NPY on electrical activity was not just the result of neuronal rundown. In contrast to cells stimulated with NPY, control neurons $(n=5)$ not stimulated by NPY showed little change in activity or membrane potential (Fig. $2 B$ ).

If glutamate receptors were blocked with AP-5 (100 $\mu \mathrm{M})$ and CNQX $(10 \mu \mathrm{M}), 6$ of 12 neurons responded to NPY with a transient hyperpolarization of -4 to $-18 \mathrm{mV}$ lasting only for the duration of peptide presence, and showing full and rapid recovery at NPY washout (Fig. 2C). In 6 of 12 neurons, no response to NPY was seen in the presence of AP-5/CNQX (Fig. 2C). NPY had no long-term effect on membrane potential or electrical activity in any neuron if endogenous glutamate activity was blocked with AP-5 and CNQX (Fig. 2E), suggesting that glutamate neurotransmission was necessary for NPY to produce effects with long durations. This was tested in additional experiments below.

\section{$\mathrm{Ca}^{2+}$ responses}

Intracellular $\mathrm{Ca}^{2+}$ can play an important role as a second messenger in a number of neuronal functions, including enzyme activation, gene expression, transmitter release, and gating ion channels (Tsien, 1987), all factors that might affect clock function. Furthermore, $\mathrm{Ca}^{2+}$ digital imaging is an excellent noninvasive approach to studying long-term effects on neurons that might be sensitive to perfusion of the intracellular milieu. To determine whether NPY influenced $\mathrm{Ca}^{2+}$ levels, we used digital imaging with Fura-2. We defined baseline $\mathrm{Ca}^{2+}$ as the cytosolic $\mathrm{Ca}^{2+}$ level for each cell in the presence of glutamate receptor blockers AP-5
$(100 \mu \mathrm{M})$ and CNQX $(10 \mu \mathrm{M})$, a condition that blocks all excitatory synaptic activity in these neurons (van den Pol and Trombley, 1993; Obrietan and van den Pol, 1995). Baseline $\mathrm{Ca}^{2+}$ levels in the absence of AP-5 and CNQX were between 40 and $100 \mathrm{nM}$. In the absence of AP-5 and CNQX, the $\mathrm{Ca}^{2+}$ levels were higher (100$200 \mathrm{nM}$ ) because of the actions of synaptically released glutamate. Of the neurons tested ( $n>600$ in 14 experiments), 95\% showed a $\mathrm{Ca}^{2+}$ depression (mean decrease, $76 \%$; minimum decrease, $15 \%)$ in response to NPY (100 nM in most experiments) in the absence of AP-5 and CNQX. Exposure to NPY caused an extended $\mathrm{Ca}^{2+}$ depression in $39 \%$ of 190 spontaneously active neurons (by at least $50 \%$ amplitude for $>10 \mathrm{~min}$ ) (Fig. $3 A-C$ ). Some neurons (6\% of 190) showed a striking $\mathrm{Ca}^{2+}$ depression to a level equivalent to blocking glutamate receptors with AP-5 and CNQX.

\section{Long-term $\mathrm{Ca}^{2+}$ depression (LTD ${ }_{\mathrm{Ca}}$ )}

In longer experiments, a brief application of NPY generated a $\mathrm{Ca}^{2+}$ depression in spontaneously active neurons that lasted for the duration of the recording $(>1 \mathrm{hr}$ ) (Fig. $3 B)$. Even a very brief $(8 \mathrm{sec})$ application of NPY $(1 \mu \mathrm{M})$ caused a $\mathrm{Ca}^{2+}$ depression that lasted $>30 \mathrm{~min}$, or 225 times longer than the exposure to the peptide (Fig. 3C1). Some neurons began returning to their preNPY $\mathrm{Ca}^{2+}$ level as soon as NPY was washed off (Fig. 3A2), whereas others in the same culture showed a long-lasting depression (Fig. 3A1). That some neurons showed a rapid recovery after NPY washout indicates that the long-term effect was not attrib- 


\section{A}
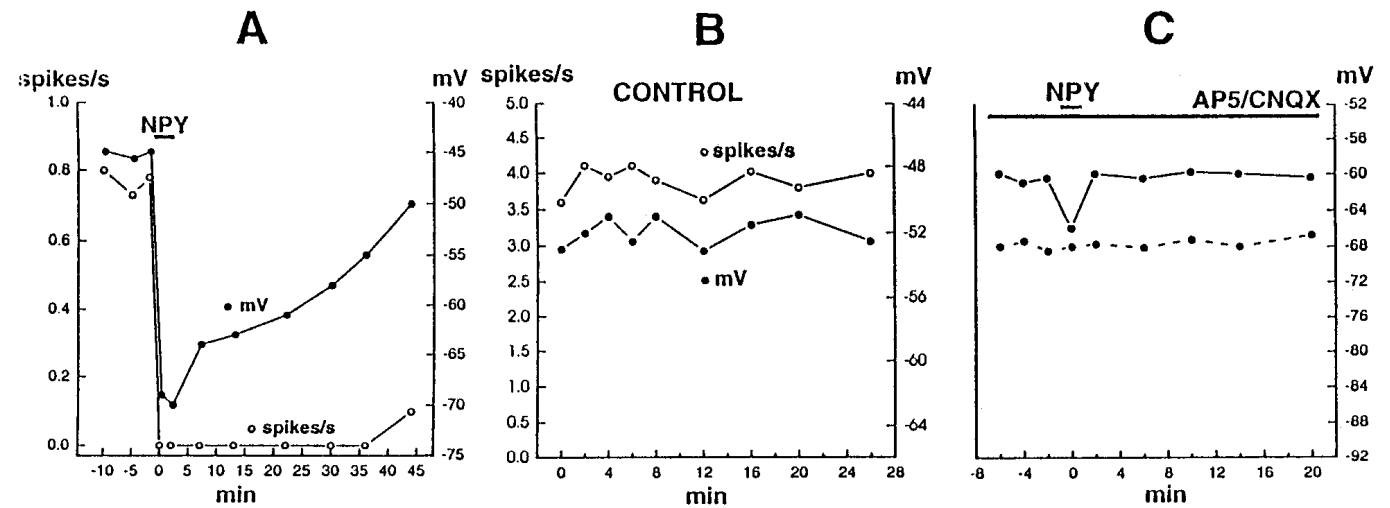

D

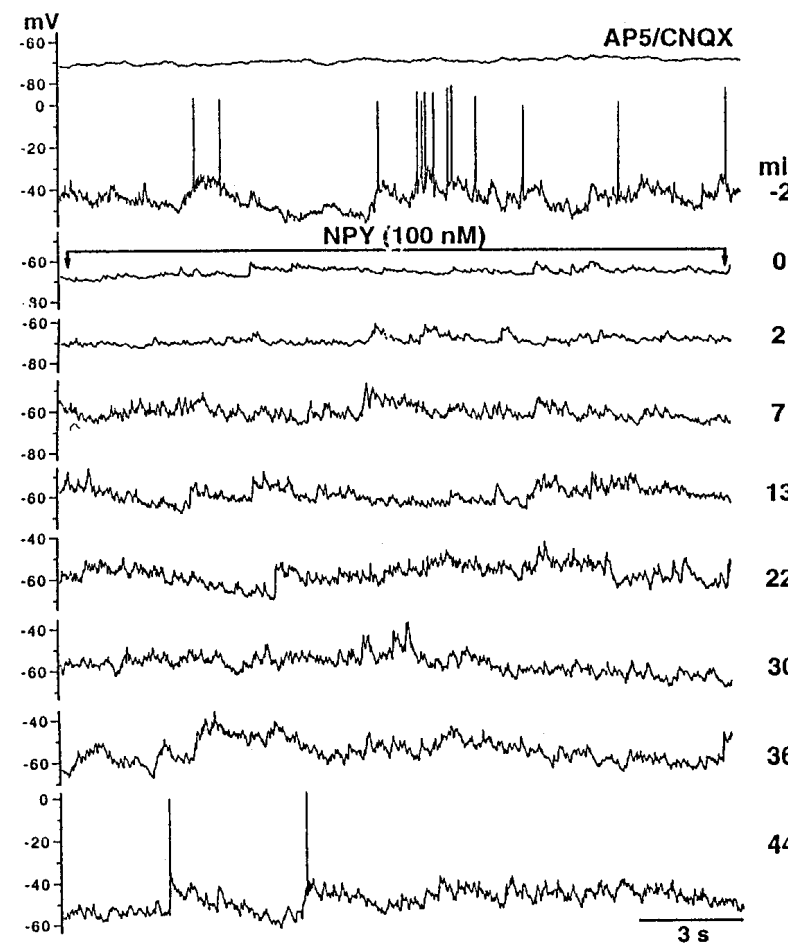

$\mathbf{E}$

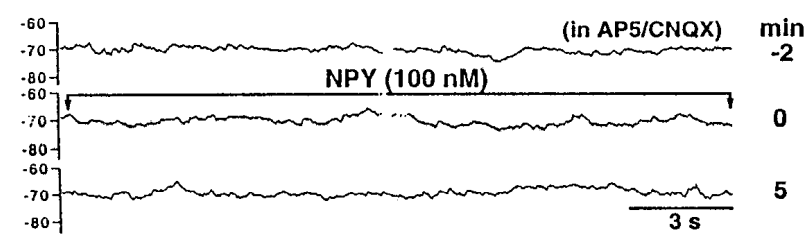

$\mathbf{F}$

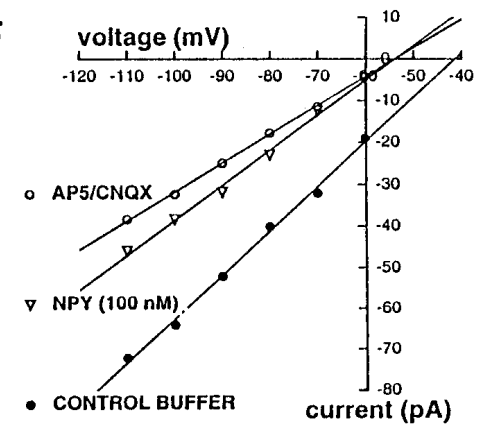

G
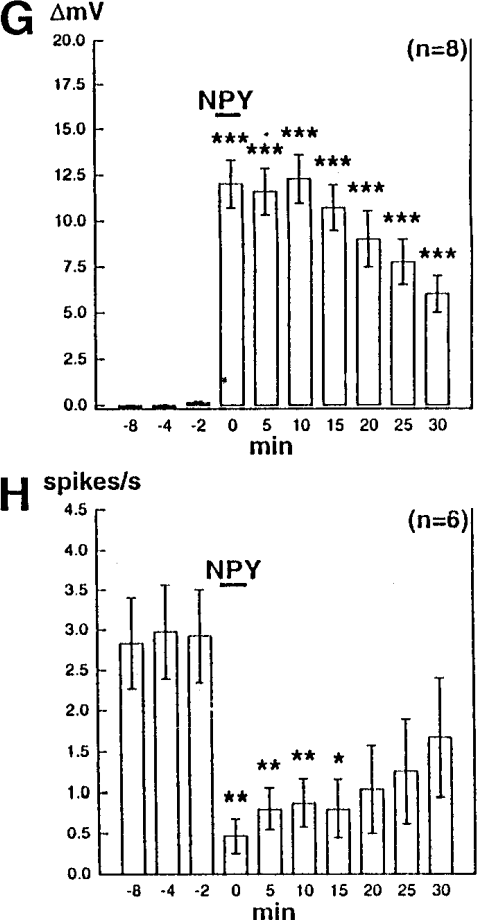

Figure 2. Whole-cell patch-clamp recording: culture. $A$, Typical change in SCN neuron spike frequency and membrane potential (mV) after 2 min application of $100 \mathrm{nM}$ NPY and subsequent recovery period in the absence of NPY. $B$, Representative control cell showing a constant membrane potential and spike frequency. $C$, In the presence of glutamate receptor blockers AP-5 (100 $\mu \mathrm{M})$ and CNQX $(10 \mu \mathrm{M})$, this SCN neuron (solid line) showed a $5 \mathrm{mV}$ hyperpolarizing response to NPY $(1 \mu \mathrm{M})$ that returned to a pre-NPY membrane potential rapidly at NPY washout, typical of neurons responding to NPY in the presence of AP-5/CNQX. Dotted line shows second neuron that did not respond to NPY. No spikes were seen in the presence of AP-5/CNQX. D, Record from a single SCN neuron before, during, and after flow-pipe application of $1 \mu \mathrm{M}$ NPY. No excitatory activity was seen in the presence of AP-5/CNQX, and activity was depressed for almost $1 \mathrm{hr}$ after a single exposure to NPY. $E$, No change in activity or membrane potential was found in this SCN neuron treated with NPY $(1 \mu \mathrm{M})$ in the presence of the glutamate receptor blockers AP-5 (100 $\mu \mathrm{M})$ and CNQX $(10 \mu \mathrm{M})$. F, I-V curve of a typical voltage-clamped neuron in three conditions: AP-5/CNQX, control with no AP-5/CNQX, and NPY in control buffer. $G$, In current-clamp experiments, NPY $(1 \mu \mathrm{M})$ caused a mean hyperpolarization $(\Delta \mathrm{V})(n=8)$ of $12-13 \mathrm{mV}$ after a 2 min application. Even after a 30 min recovery period, the membrane potential had only made a partial recovery. Asterisks indicate groups statistically different from controls; *** $p<0.001$. $H$, Mean spike frequency after 2 min exposure to $1 \mu \mathrm{M}$ NPY $(n=6)$ was reduced sixfold. Recovery was not complete even after extended recovery times. Asterisks denote groups significantly different from pre-NPY control data (two-tailed $t$ test); ${ }^{* *} p<0.01,{ }^{*} p<0.05$. All cells in this group responded to NPY, some with long-term and some with short-term responses. Error bars indicate SEM. 


\section{A. NPY INHIBITION OF ENDOGENOUS, GLUTAMATE-DEPENDENT Ca ${ }^{2+}$ RISE}
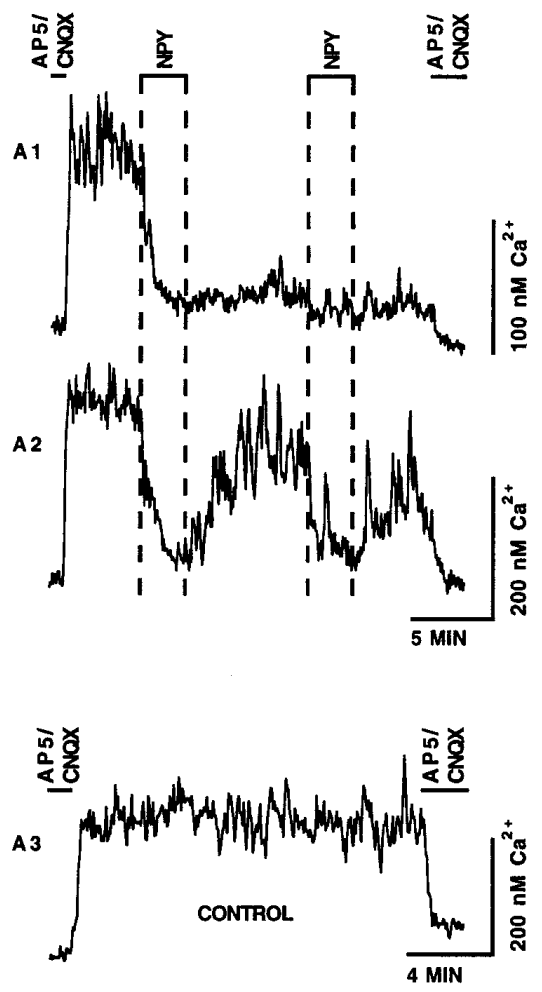

E. NPY AGONISTS REDUCE Ca ${ }^{2+}$-DEPENDENT ENDOGENOUS GLUTAMATE ACTIVITY

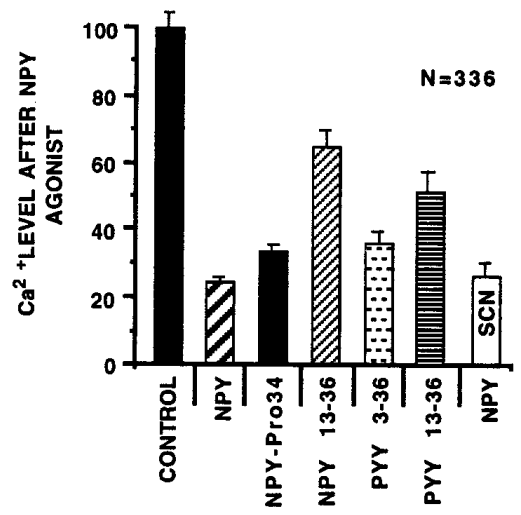

B. LONG TERM DEPRESSION $>1$ HR
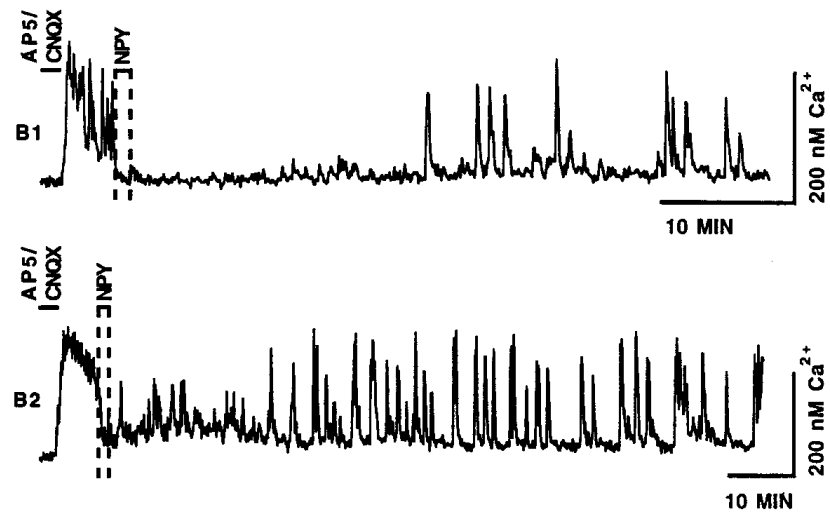

C. LONG TERM DEPRESSION WITH NPY EXPOSURE
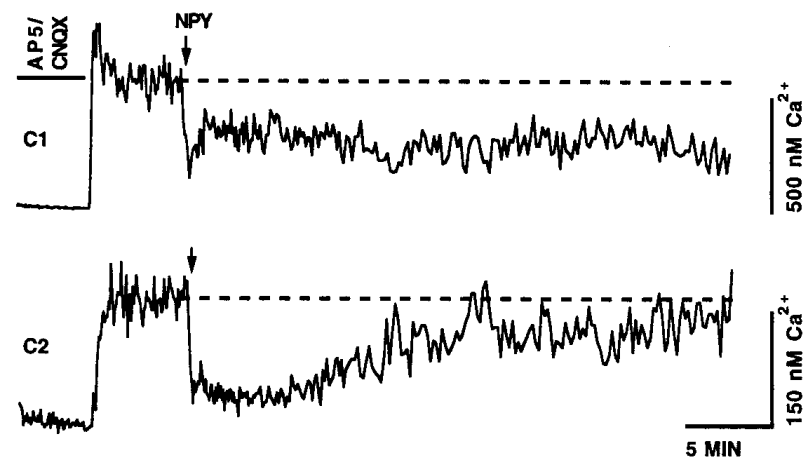

D. NPY RECEPTOR AGONISTS

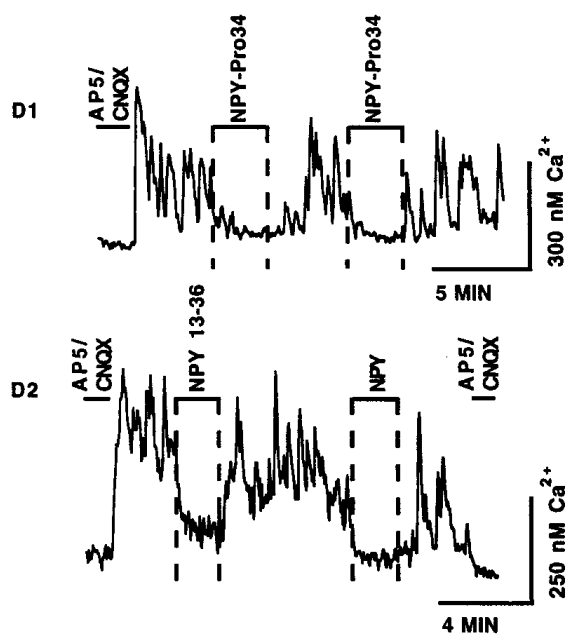

Figure 3. Fura-2 $\mathrm{Ca}^{2+}$ digital imaging. In these experiments, the effect of NPY receptor agonists (100 nM) was examined on spontaneously active synaptically coupled neurons. Glutamate receptor antagonists AP-5 $(100 \mu \mathrm{M})$ and CNQX $(10 \mu \mathrm{M})$ blocked excitatory activity and were used in some experiments to allow a comparison of the relative efficacy of NPY in reducing activity. $A, A 1$, and $A 2$ are two SCN neurons recorded simultaneously. $A 1$

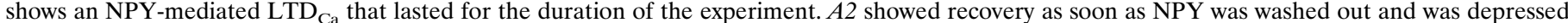
by a second application of NPY. $A 3$ is a control neuron showing a typical maintenance of $\mathrm{Ca}^{2+}$ levels over the course of recording. NPY was not applied to this neuron. $B$, A 2 min application of NPY led to an $\mathrm{LTD}_{\mathrm{Ca}}$ that lasted $>90 \mathrm{~min}$. B1, Partial recovery of $\mathrm{Ca}^{2+}$ spikes after $45 \mathrm{~min}$ is seen, but the level of activity and elevated $\mathrm{Ca}^{2+}$ baseline did not recover. B2, The baseline shows an LTD after NPY exposure, but $\mathrm{Ca}^{2+}$ spikes continued. $C 1$, An 8 sec application of NPY depressed cytosolic $\mathrm{Ca}^{2+}$ for the length of the experiment. $C 2$ shows partial recovery after 10 min. $D$, Application of Y1 agonist $\left[\mathrm{Leu}^{31}, \mathrm{Pro}^{34}\right]$-NPY designated NPY-Pro ${ }^{34}(D 1)$ and Y2 agonist NPY13-36 (D2) caused substantial reductions in $\mathrm{Ca}^{2+}$ baseline and transient activity. $E$, Relative efficacy of NPY agonists in reducing $\mathrm{Ca}^{2+}$. Although not tested for relative effectiveness, examples of $\mathrm{LTD}_{\mathrm{Ca}}$ were found after each of the NPY agonists. Error bars indicate SEM. Number of cells tested for each agonist, in same sequence as bars, left to right: $n=103$ (NPY tested in general medial hypothalamic cultures), 42 ([Leu ${ }^{31}$, Pro $\left.^{34}\right]$-NPY), 69 (NPY13-36), 35 (PYY3-36), 47 (PYY13-36), 40 (tested in SCN cultures). The Ca ${ }^{2+}$ level in each group before NPY agonist application served as the control level (100\%). Both selective SCN and general medial hypothalamic cultures showed very similar amplitudes of responses. 
utable to partial washout of the NPY or to a general adhesion of the peptide to cells. Control neurons not stimulated with NPY maintained constant mean $\mathrm{Ca}^{2+}$ levels (Fig. 3A3).

\section{Receptor-selective agonists}

To determine which NPY receptor types might be involved in the depression of cytosolic $\mathrm{Ca}^{2+}$, we used Y1 ([Leu $\left.\left.{ }^{31}, \mathrm{Pro}^{34}\right]-\mathrm{NPY}\right)$ (Fig. 3D1) and Y2 [NPY13-36 (Fig. 3D2) and PYY13-36] preferring agonists (Wahlestedt et al., 1990) and examined the effects of these agonists on spontaneously active neurons. Figure $3 E$ shows the relative $\mathrm{Ca}^{2+}$ depression elicited by different $\mathrm{Y} 1$ and $\mathrm{Y} 2$ agonists. NPY had the greatest effect, but all agonists evoked a strong $\mathrm{Ca}^{2+}$ depression, suggesting that both Y1- and Y2-like receptors were involved in reducing ongoing activity.

\section{Postsynaptic effects}

In the experiments above showing NPY effects on spontaneously active neurons, the $\mathrm{Ca}^{2+}$ depression could be attributable to either presynaptic or postsynaptic NPY receptors, or both. Previous work in the hippocampus (Colmers et al., 1991; Bleakman et al., 1992, 1993) and raphe (Kombian and Colmers, 1992) suggested that NPY acted by a presynaptic mechanism; postsynaptic effects were not detected, except in a recent report in hippocampal granule cells (McQuiston et al., 1996). In contrast, in the present study, SCN neurons and hypothalamic neurons in general showed striking NPY-mediated depressions of $\mathrm{Ca}^{2+}$ rises evoked by coapplication of glutamate $(20 \mu \mathrm{M})$ applied by rapid bath perfusion. Neurons did not respond to NPY with a change in cytosolic $\mathrm{Ca}^{2+}$ in the absence of glutamate. These experiments were performed in the presence of tetrodotoxin (TTX) $(1 \mu \mathrm{M})$ to block action potential-dependent synaptic release of transmitters and, therefore, a mechanism involving secondary release of unidentified transmitters is unlikely. Because these effects cannot be explained by modulation of presynaptic release, the results suggest that cytosolic $\mathrm{Ca}^{2+}$ levels in hypothalamic neurons can be regulated by NPY modulating a postsynaptic response to glutamate. Only a very small number of cells (1\% of 167) showed a delayed recovery $\left(\mathrm{LTD}_{\mathrm{Ca}}\right)$ after NPY stimulation (Fig. $4 A$, top), whereas most recovered by the subsequent transmitter stimulation (Fig. 4A, bottom), suggesting that long-term actions of NPY probably were not mediated postsynaptically.

To determine whether Y1- or Y2-like receptors were responsible for the postsynaptic $\mathrm{Ca}^{2+}$ depression, we tested a number of NPY agonists. Both Y1 and Y2 receptor agonists (100 nM) including NPY (Fig. 4A), [Leu ${ }^{31}$,Pro $\left.{ }^{34}\right]$-NPY (Fig. 4B), NPY13-36 (Fig. $4 C, D$ ), PYY13-36 (Fig. 4E), and PYY3-36 (Fig. $4 F$ ) reduced the amplitude of the $\mathrm{Ca}^{2+}$ rise evoked by glutamate $(20 \mu \mathrm{M})$. Interestingly, the most effective agonist was PYY3-36, which depressed glutamate-evoked $\mathrm{Ca}^{2+}$ rises even more than NPY itself (Fig. $4 G, H)$. That PYY3-36 has a modulatory effect greater than NPY raises the question of whether it may be acting on a novel hypothalamic Y-type receptor or whether it is activating a Y2 or Y5 receptor (Gerald et al., 1996). PYY is a gut hormone with a $69 \%$ amino acid sequence homology to NPY (Tatemoto et al., 1982), and its presence in the brain has been suggested (Broome et al., 1985). PYY has been suggested to be equipotent with NPY in its actions on Y1 and Y2 receptors (Walker and Miller, 1988; Wahlestedt et al., 1992; Foucart et al., 1993). PYY3-36 is not working through a putative $\mathrm{Y} 3$ receptor, because that receptor is thought to be insensitive to PYY activation (Grundemar et al., 1993). The sensitivity of the postsynaptic effect to PYY3-36 is in contrast to the experiments with spontaneously active cells that found NPY itself was the most effective agonist in reducing $\mathrm{Ca}^{2+}$. This difference may be attributable to receptors with greater PYY sensitivity postsynaptically and a greater NPY sensitivity presynaptically.

The relative efficacies of NPY agonists in modulating postsynaptic glutamate responses in 820 trials are shown in Figure $4, G$ and $H$. Each neuron was stimulated with glutamate and two NPY agonists in the presence of TTX $(1 \mu \mathrm{M})$. Two neurons are shown for each experiment, revealing different relative sensitivities to NPY agonists. The heterogeneous response of single neurons to application of different NPY agonists suggests that a single cell may express several different types of NPY receptors on the cell soma.

\section{Mechanisms of NPY action}

We have suggested previously that most of the fast synaptic activity in the hypothalamus was mediated by glutamate and GABA, and that a principal role of hypothalamic peptides was to modulate these fast amino acid transmitters (van den Pol et al., 1990). To test further this hypothesis, we undertook a series of experiments to examine the mechanism of NPY action. These experiments were also designed so that we could compare possible mechanisms of LTD in the hypothalamus with that reported previously by other laboratories examining LTD in cortical brain regions.

Because an NPY-mediated reduction of activity could be attributable to an NPY enhancement of GABA inhibitory activity, we blocked the $\mathrm{GABA}_{\mathrm{A}}$ receptor with bicuculline $(20 \mu \mathrm{M})$. In contrast to previous reports of GABAergic involvement in some other models of LTD (Thiels et al., 1994; Yang et al., 1994; Obrietan and van den Pol, 1996), we found that blocking the GABA receptors did not interfere with NPY-mediated long-term (Fig. 5A1) or short-term (Fig. 5A2) $\mathrm{Ca}^{2+}$ depression in mature neurons. Previous work on hippocampal LTD has suggested that the NMDA receptor is a necessary component of many forms of LTD (Dudek and Bear, 1992; Mulkey and Malenka, 1992). However, blocking the hypothalamic NMDA receptor with AP-5 (100 $\mu \mathrm{M})$ did not block $\mathrm{LTD}_{\mathrm{Ca}}$ (Fig. $5 \mathrm{C}$ ). Other reports have demonstrated the crucial importance of voltage-gated $\mathrm{Ca}^{2+}$ channels in the induction of hippocampal LTD (Bolshakov and Siegelbaum, 1994). In contrast, selective blockade of the L-type (Fig. $5 B$ ) or $\mathrm{N}$-type (Fig. $5 D$ ) voltage-activated $\mathrm{Ca}^{2+}$ channel in hypothalamic neurons with nimodipine $(1 \mu \mathrm{M})$ or conotoxin $(1 \mu \mathrm{M})$ did not block the NPY extended reduction of $\mathrm{Ca}^{2+}$ in hypothalamic neurons, but did reduce the amplitude of the NPY effect, as shown in Figure 5. Involvement of the $\mathrm{N}$ channel is potentially interesting in light of the finding that NPY acted through an N-type $\mathrm{Ca}^{2+}$ channel in its action on terminals of sympathetic neurons (Toth et al., 1993). The possibility remains that one or more voltage-gated $\mathrm{Ca}^{2+}$ channels may mediate part of the long-term effect of NPY, but that a single type may not account for the entire response.

To test the hypothesis that $\mathrm{G}_{\mathrm{i}}$ or $\mathrm{G}_{\mathrm{o}} \mathrm{G}$-proteins were necessary for the long-term effect of NPY, we treated the cells with pertussis toxin (PTX) (Colmers et al., 1991; Bleakman et al., 1992, 1993). Neurons treated with PTX showed no response to NPY (Fig. 5E), whereas control neurons from sister cultures did show strong depressions. AP-5 and CNQX decreased $\mathrm{Ca}^{2+}$ in PTX-treated neurons, indicating that the cells were healthy and capable of regulating cytosolic $\mathrm{Ca}^{2+}$. These results demonstrate that NPY action may be dependent on a PTX-sensitive G-protein-coupled mechanism. 


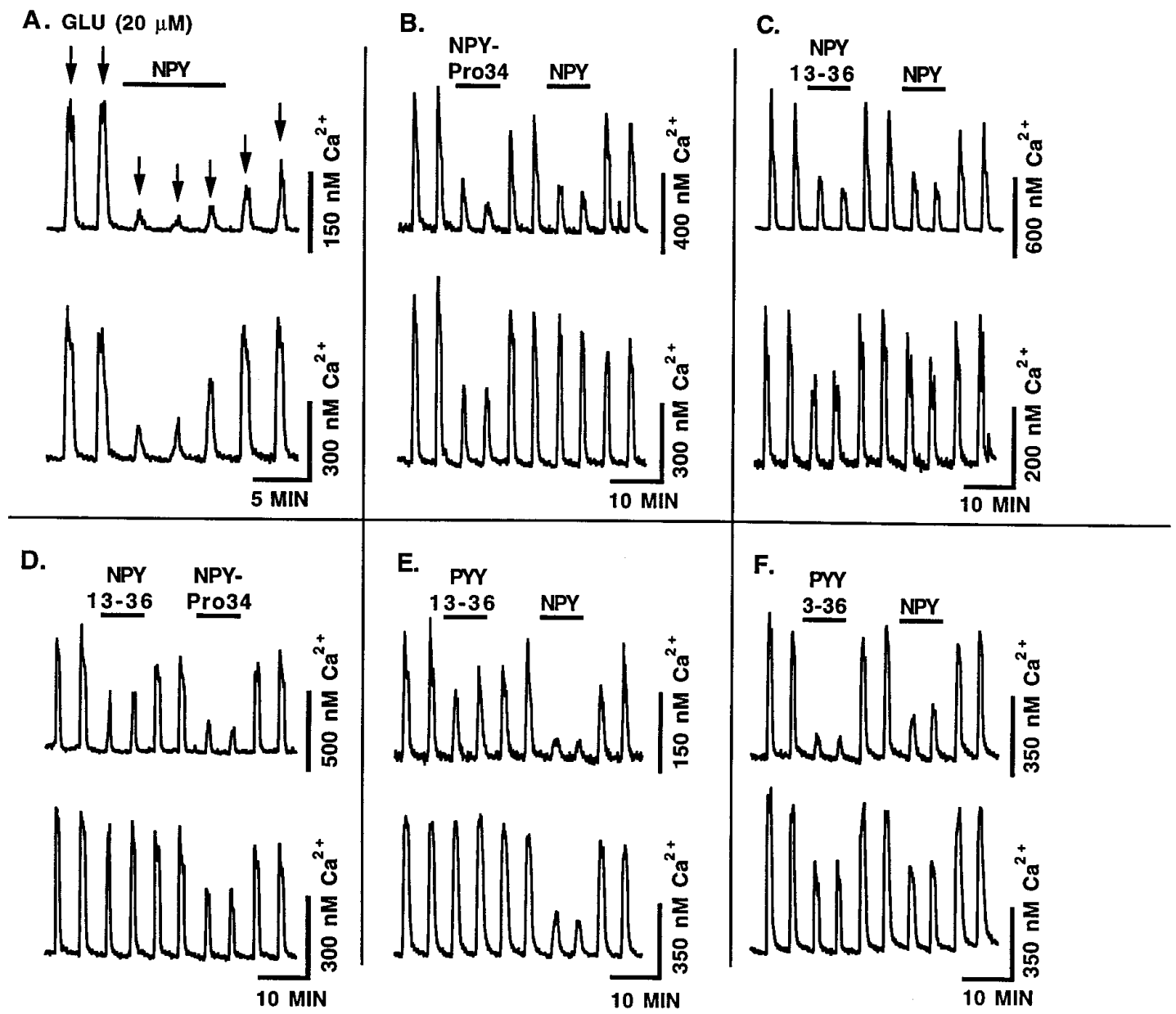

\section{G. POSTSYNAPTIC RESPONSE TO GLUTAMATE DEPRESSED BY NPY RECEPTOR AGONISTS}

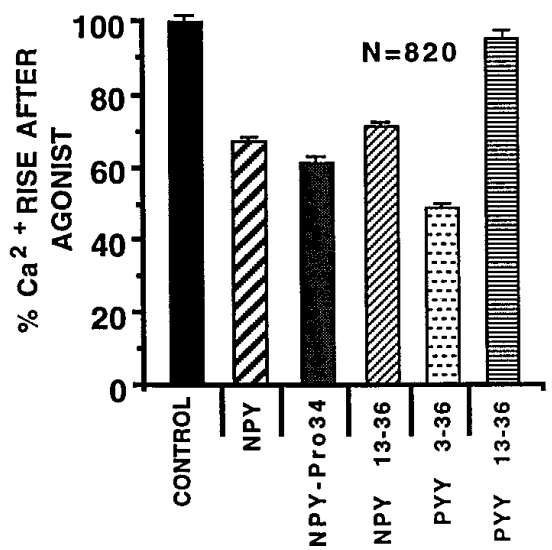
H. \% NEURONS WITH $\mathrm{Ca}^{2}+$ RISE DEPRESSED $>20 \%$ BY NPY RECEPTOR AGONISTS

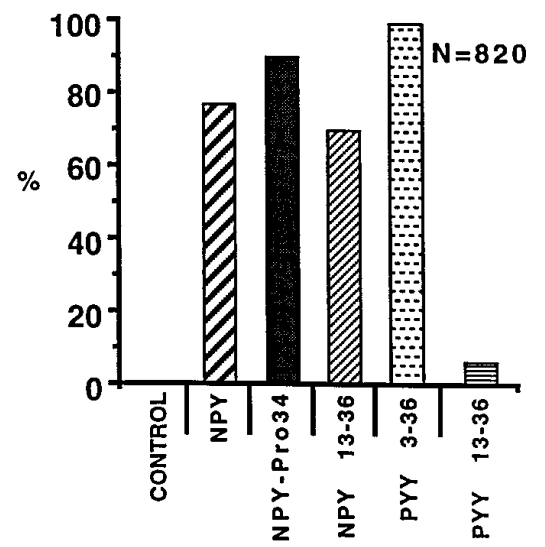

Figure 4. NPY receptor agonists modulate postsynaptic glutamate responses: Fura-2. In these experiments with 820 tests, glutamate $(20 \mu \mathrm{M})$ was added to each neuron several times ( $30 \mathrm{sec}$ application duration). Each spike represents the addition of glutamate. NPY agonists were coapplied with glutamate as indicated by the horizontal lines. All agonists were $100 \mathrm{nM}$. TTX $(1 \mu \mathrm{M})$ was used in the buffer to prevent release of endogenous transmitters that might complicate data interpretation. Two representative neurons recorded simultaneously are shown for each condition. Because we found no difference in the responses of selective SCN cultures and medial hypothalamic cultures that included the SCN, data are pooled here. In $A$, NPY (horizontal bar) was applied $30 \mathrm{sec}$ before the third glutamate (arrows) application. In the atypical upper neuron, even after $10 \mathrm{~min}$, the cell did not recover to its pre-NPY glutamate-evoked $\mathrm{Ca}^{2+}$ amplitude. The lower cell recovered as soon as NPY was removed. In $B-F$, the relative efficacy of two NPY agonists is compared. $G$ and $H$ show the relative efficacy of different NPY agonists. $G$ shows the mean glutamate-evoked $\mathrm{Ca}^{2+}$ rise in the presence of NPY agonists, and $H$ shows the percent neurons within each group that showed a NPY-mediated depression of glutamate-evoked $\mathrm{Ca}^{2+}$ rises. Control is the response to glutamate in the absence of NPY agonists. Number of cells tested with each agonist, $n=412$ (NPY), 181 (NPY13-36), 114 [Leu ${ }^{31}$,Pro $\left.^{34}\right]-$ NPY called NPY-Pro $^{34}$, 53 (PYY13-36), and 60 (PYY3-36). PYY3-36 was the most effective $(p<0.05)$, whereas the shorter C-terminal fragment PYY13-36 was least effective. 


\section{A. NPY INHIBITION IS NOT DEPENDENT ON GABA A RECEPTOR INHIBITION}

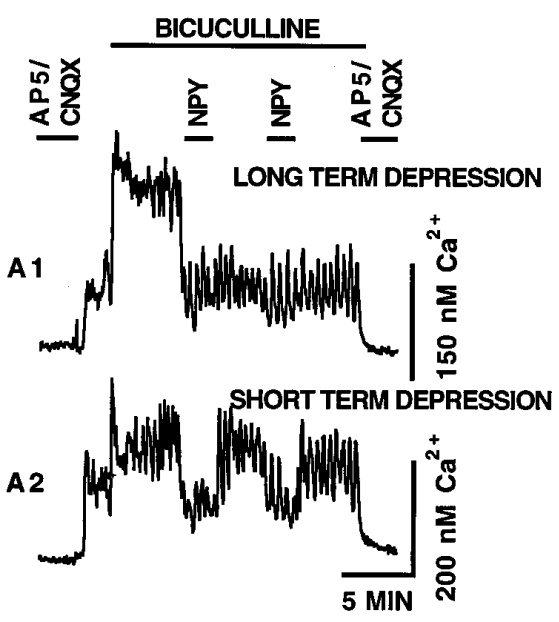

C. LONG TERM DEPRESSION IS NOT DEPENDENT ON NMDA RECEPTOR

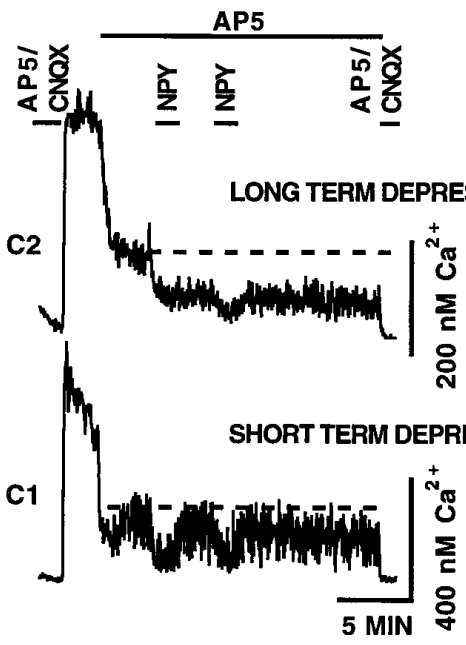

E. NPY INHIBITION IS MEDIATED BY Gi/Go PROTEINS; PERTUSSIS TOXIN PRETREATMENT INHIBITS THE EFFECTS OF NPY

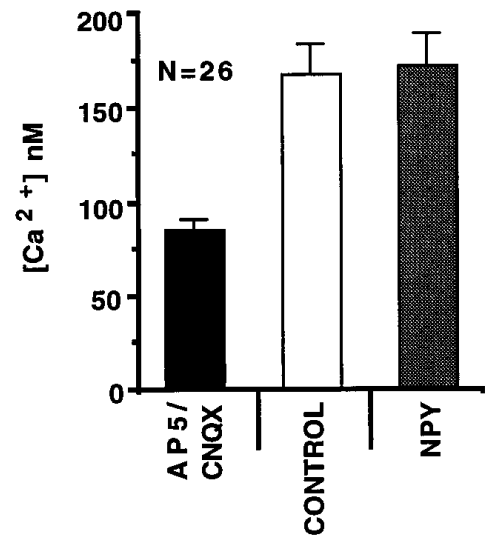

Presynaptic site of NPY action: culture and slice

To test further the hypothesis that NPY acted at presynaptic axons, we used TTX $(1 \mu \mathrm{M})$ to block $\mathrm{Na}^{+}$-dependent action potentials in cultured neurons, and examined the frequency of miniature EPSCs (mEPSCs) in cultures of medial hypothalamus

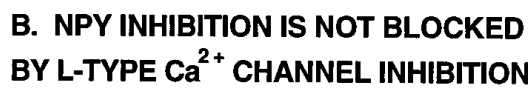

BY L-TYPE $\mathrm{Ca}^{2+}$ CHANNEL INHIBITION

NIMODIPINE
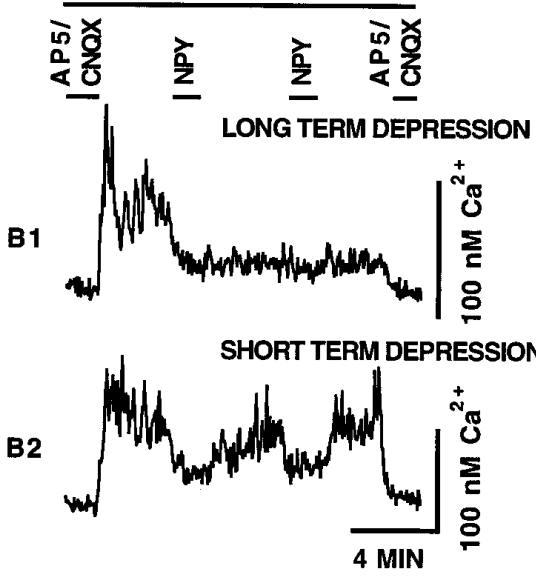

D. NPY INHIBITION IS NOT BLOCKED BY N-TYPE $\mathrm{Ca}^{2+}$ CHANNEL INHIBITION
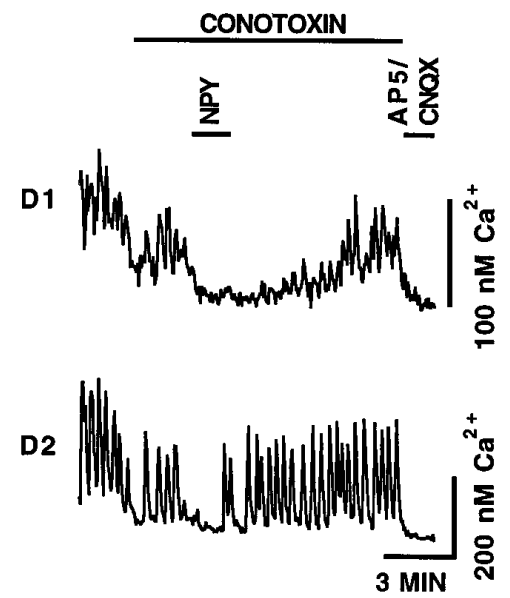

Figure 5. Mechanisms of NPY action. $A$, The GABA antagonist bicuculline $(20 \mu \mathrm{M})$ did not block either NPY-mediated long- or short-term $\mathrm{Ca}^{2+}$ depression $(n=28) . B$, Blocking the L-type voltage-activated $\mathrm{Ca}^{2+}$ channel with nimodipine $(1 \mu \mathrm{M})$ did not block NPY-mediated long- or short-term $\mathrm{Ca}^{2+}$ depression $(n=50) . C$, Blocking the NMDA receptor with AP-5 $(100 \mu \mathrm{M})$ caused a reduction in general $\mathrm{Ca}^{2+}$ levels, but did not block NPY-mediated long- or short-term $\mathrm{Ca}^{2+}$ depressions $(n=39) . D$, Blocking the N-type voltage-activated $\mathrm{Ca}^{2+}$ channel with $\omega$-conotoxin (1 $\mu \mathrm{M})$ did not block NPY-mediated long- or short-term $\mathrm{Ca}^{2+}$ depression $(n=58)$. E, Preincubation with PTX $(150 \mathrm{ng} / \mathrm{ml}$ for $17 \mathrm{hr}$ ) completely blocked the NPY depression (compare lack of depression with the NPYmediated depression in the second error bar in Fig. $3 E)$, indicating the involvement of $\mathrm{G}_{\mathrm{i} /} \mathrm{G}_{\mathrm{o}}$ proteins $(n=$ 26). In contrast, control application of AP-5 (100 $\mu \mathrm{M})$ and CNQX $(10 \mu \mathrm{M})$ generated a significant drop in cytosolic $\mathrm{Ca}^{2+}$.

that contained the SCN. Neurons were voltage clamped at -60 $\mathrm{mV}$ in the presence of bicuculline $(20 \mu \mathrm{M})$ to block the actions of synaptically released GABA. Eight of 13 neurons tested responded to NPY, and all 8 showed a decrease in the frequency of mEPSCs. Three of the eight showed a depression in mEPSC 
A
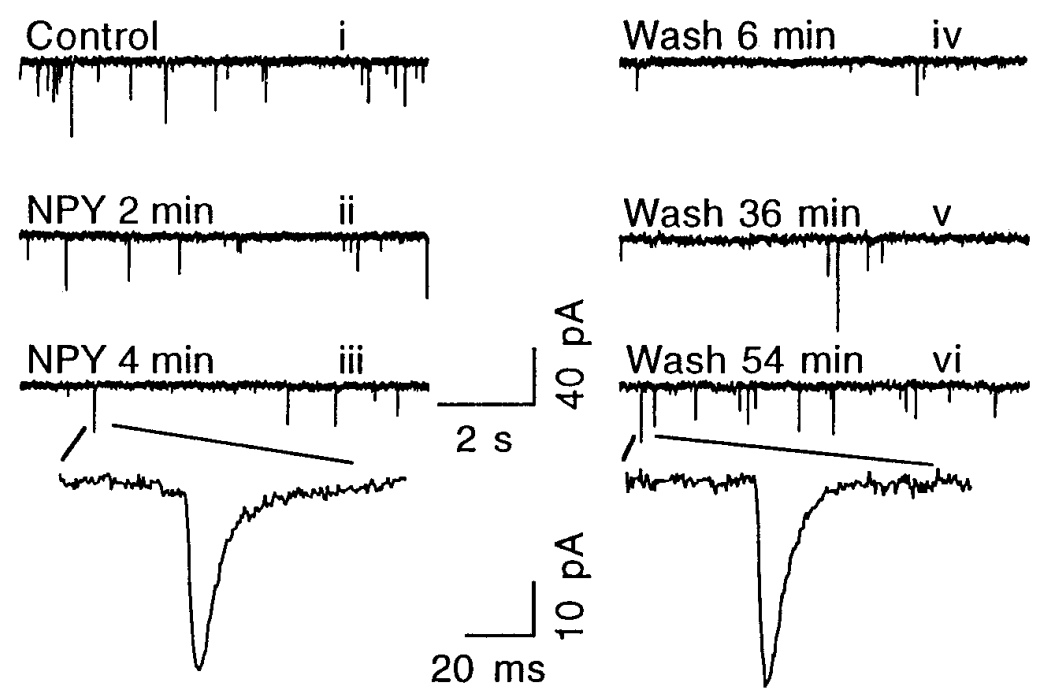

B

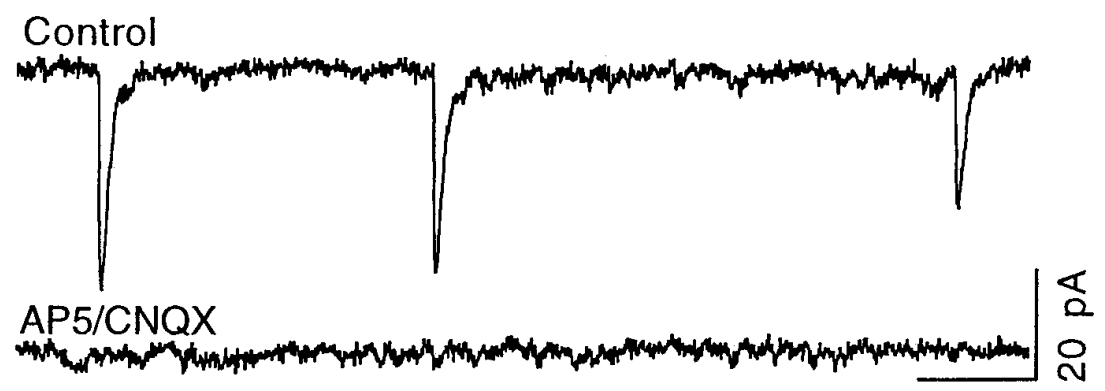

$\mathrm{C}$

$100 \mathrm{~ms}$

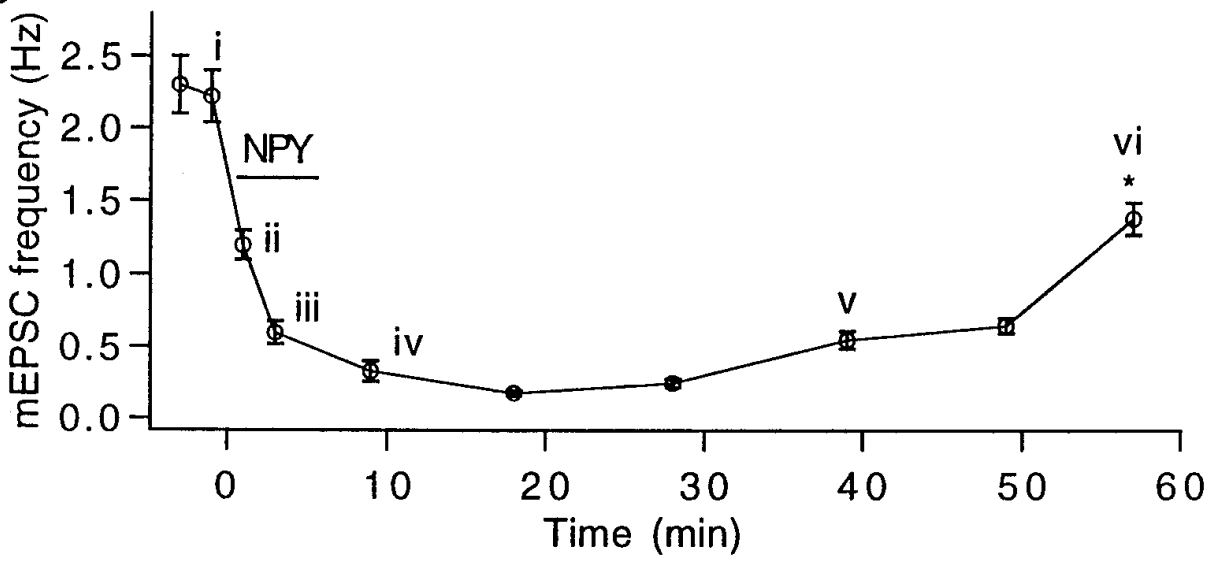

Figure 6. Presynaptic NPY action: LTD of mEPSCs. $A$, In this example, the frequency of EPSCs was reduced by a $4 \mathrm{~min}$ exposure to NPY $(200 \mathrm{nM})$ in a voltageclamped neuron $(-60 \mathrm{mV})$ and remained depressed long after NPY washout. Two miniature events are shown in greater detail at the bottom of $A$, indicating that the time course and amplitude of the EPSC did not change from the beginning of the experiment to the end (54 $\mathrm{min})$. All buffers contained TTX $(1 \mu \mathrm{M})$ to block spikedependent transmitter release. $B$, AP-5 $(100 \mu \mathrm{M})$ and CNQX $(100 \mu \mathrm{M})$ completely blocked EPSCs, indicating glutamate as the transmitter. Washout of AP-5/CNQX resulted in recovery of EPCSs (data not shown). $C$, The time course of the raw data in $A$ are shown over the entire recording period. The SEMs are shown by the small error bars at each time interval, based on seven to eight consecutive samples of 30 sec duration. All points from the first one after NPY introduction to the last one at the end of the experiment (asterisk) were significantly different from pre-NPY EPSC frequency.

frequency lasting for the duration of the recording period (mean, $1 \mathrm{hr}$ ). Figure 6 shows an example of one neuron in which NPY application (4 min duration) reduced mEPSC frequency by $80 \%$. Figure $6 A$ shows representative EPSCs during different stages of the recording. The EPSCs were fully blocked by the addition of AP-5 $(100 \mu \mathrm{M})$ and CNQX $(10 \mu \mathrm{M})$, indicating that they were caused by glutamate release (Fig. $6 B$ ). The time course is shown in Figure $6 C$. Even $1 \mathrm{hr}$ after NPY washout, the mEPSC frequency still was significantly lower $(p<0.05)$ than pre-NPY levels. That the frequency was starting to return to pre-NPY levels at the end of the experiment suggests that the frequency reduction was not simply attributable to a compromised cell showing run- down. The magnitude of the mEPSCs showed no decrease over the course of the experiments, suggesting that the results were not attributable to increases in access resistance.

Parallel experiments were performed in SCN slices under voltage clamp $(-75 \mathrm{mV})$. These slice experiments have the advantage that the responses of the existing circuitry and axonal innervation of identified SCN neurons could be studied. In the example shown in Figure 7, the frequency of spontaneous mEPSCs in TTX $(1 \mu \mathrm{M})$ showed a significant decrease after NPY (500 nM) bath application. The frequency remained depressed for long recording periods ( $1 \mathrm{hr})$. During that time, current injections were used to show that the membrane input resistance remained stable $(445 \pm 20$ 


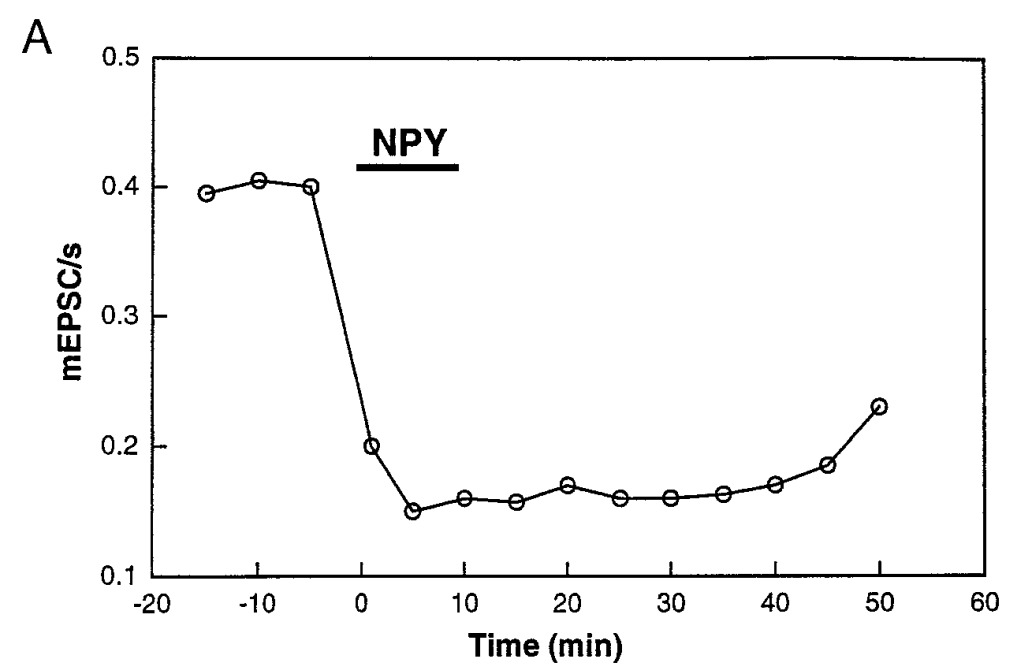

B

Figure 7. mEPSCs in SCN slice. mEPSCs were recorded in an SCN neuron in the presence of TTX (1 $\mu \mathrm{M})$, and bicuculline $(50 \mu \mathrm{M}) . A$, A decrease in the frequency of mEPSCs was seen when NPY (500 nM) was bath applied (horizontal line). After NPY was washed out, the mEPSC frequency remained depressed for the duration of the recording period. $B$, Representative traces during the course of the experiment are shown with the time in minutes on the right of each trace. NPY was added at 0 time. $C$, mEPSCs from the record above $(B)$ are shown in the boxed area at the bottom with a faster time sweep. Holding potential, $-75 \mathrm{mV}$.

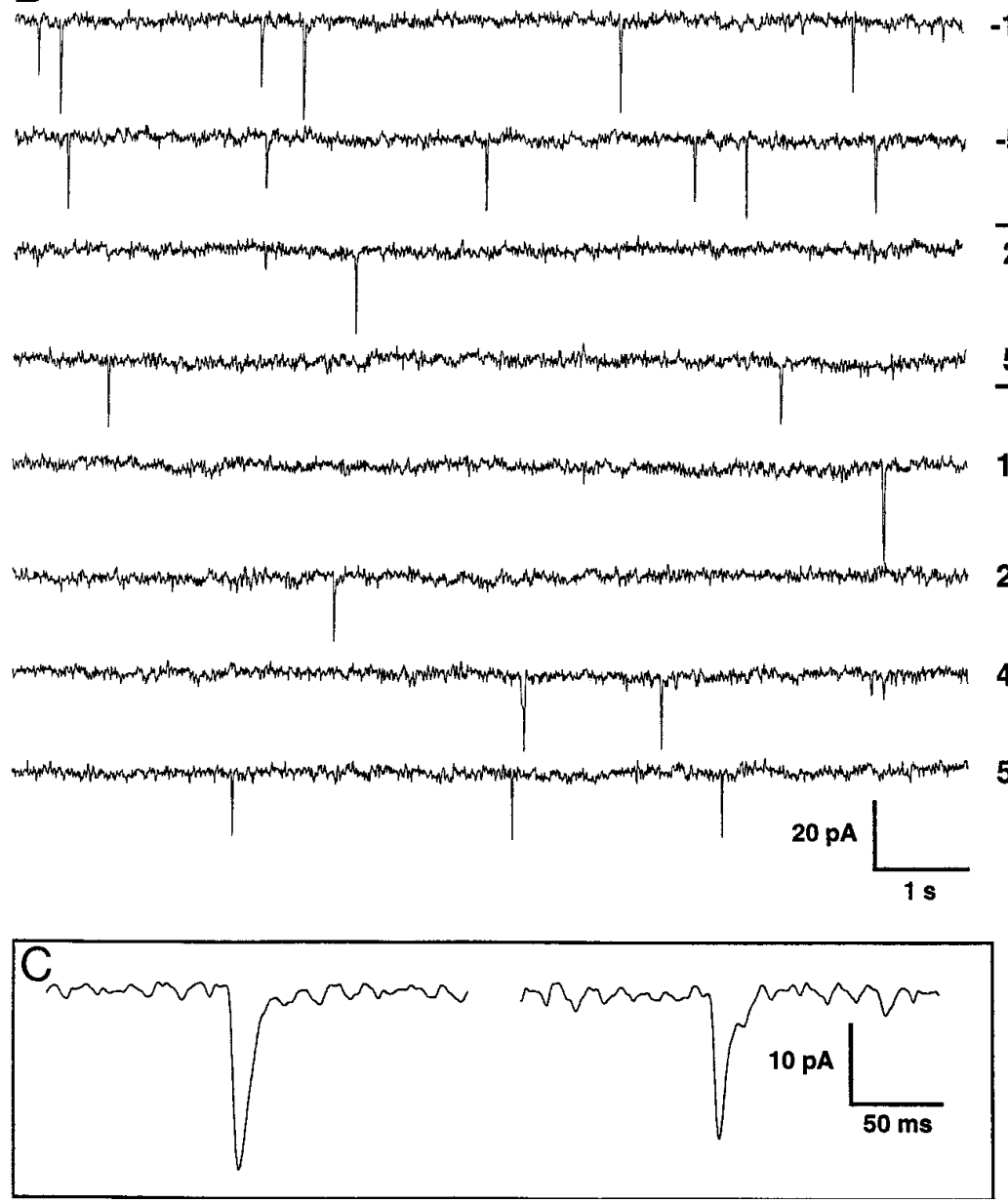

$\mathrm{M} \Omega$ ). Bicuculline $(50 \mu \mathrm{M})$ was used in all solutions to block GABA-mediated IPSCs. mEPSCs could be fully blocked with AP-5 $(100 \mu \mathrm{M})$ and CNQX $(10 \mu \mathrm{M})$ (data not shown), indicating that glutamate release was responsible for the EPSCs. All mPSCs were effectively blocked with the combination of GABA and glutamate receptor antagonists bicuculline and AP-5/CNQX. Thus, the slice work is consistent with and fully supports the conclusions based on experiments with cultured neurons.
Long-term effects require coincident activation of NPY and glutamate receptors

In a particularly interesting set of experiments, we tested the hypothesis that NPY would exert a long-lasting effect on cytosolic $\mathrm{Ca}^{2+}$ only if glutamate activity were ongoing at the time of NPY application. We therefore added NPY (100 nM) in the presence of glutamate receptor antagonists, and 2 min later removed NPY and then washed out the glutamate receptor antagonists. In these 


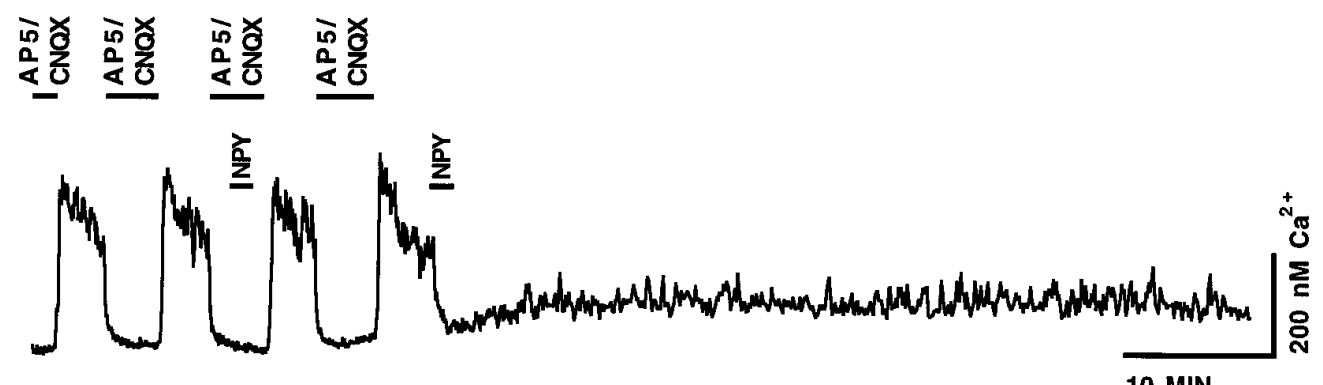

experiments $(n=102)$ we found no cases in which NPY would exert either an immediate or a latent effect on glutamatemediated $\mathrm{Ca}^{2+}$ activity (Fig. 8). This is in striking contrast to our previous observation of $\mathrm{LTD}_{\mathrm{Ca}}$ lasting $90 \mathrm{~min}$ (e.g., Fig. $3 B$ ) if NPY was applied during ongoing glutamate activity. To demonstrate that the cells would respond to NPY, we removed the AP-5/CNQX glutamate receptor block from the same cells and found that NPY then did exert a long-lasting depression of activity on one third of the group of neurons $(n=102)$ that showed no immediate or latent response to NPY in the presence of glutamate receptor antagonists (Fig. 8). These results indicate that glutamate-dependent activity was necessary for NPY to influence intracellular $\mathrm{Ca}^{2+}$.

\section{DISCUSSION}

Taken together, our experiments suggest that both Y1- and Y2like NPY receptors are functionally expressed at both presynaptic and postsynaptic sites; this has not been reported in other regions of the CNS. NPY depressed both the intracellular $\mathrm{Ca}^{2+}$ and the electrical activity of neurons, in part by a presynaptic mechanism that reduced glutamate release from axons bearing NPY receptors. Both the induction and the expression of a long-term depression of excitatory activity, found with whole-cell recording in cultures and slices and with noninvasive digital $\mathrm{Ca}^{2+}$ imaging, was dependent on the simultaneous release of glutamate and NPY receptor activation.

\section{Widespread NPY receptor expression}

In contrast to studies based on radioactive ligand binding suggesting that NPY receptor expression is relatively low in the hypothalamus (Lynch et al., 1989), our data, based on both patchclamp recording and digital imaging, indicate that almost all hypothalamic neurons in vitro are influenced by presynaptic or postsynaptic functional NPY receptors. Acting both presynaptically and postsynaptically, NPY can cause a substantial depression of cytosolic $\mathrm{Ca}^{2+}$ and glutamate-mediated excitatory activity, not only in SCN neurons but also in other mediobasal hypothalamic neurons.

The magnitude of the $\mathrm{Ca}^{2+}$ depression elicited by NPY in spontaneously active neurons, considered as a percentage decrease, was two to three times greater than the depression elicited during responses evoked by glutamate application. This was true over a range of glutamate-regulated $\mathrm{Ca}^{2+}$ levels. Because the evoked responses were done in the presence of TTX, and would demonstrate postsynaptic actions, the greater effects of NPY on
Figure 8. NPY in the presence of glutamate receptor antagonists AP-5 and $\mathrm{CNQX}$ had no $\mathrm{Ca}^{2+}$ effect, either at the time of NPY application or after the rapid removal of the glutamate receptor antagonists $(n=102)$. For control purposes, AP-5 and CNQX were washed off twice, and each time a large increase in cytosolic $\mathrm{Ca}^{2+}$ was found. NPY (100 nM) then was added in the presence of AP-5 and CNQX, and NPY then was washed out. Thirty seconds later, AP-5/CNQX was washed out, and no effect of NPY was detected. However, on a subsequent trial, in the absence of AP-5 and CNQX, NPY evoked a large decrease in $\mathrm{Ca}^{2+}$ that persisted for the duration of the recording session. spontaneously active cells were probably attributable to additional presynaptic effects of the peptide. This is consistent with the relative absence of long-term action of NPY on glutamate-evoked postsynaptic responses, but a sizable $\mathrm{LTD}_{\mathrm{Ca}}$ in $39 \%$ of spontaneously active neurons. In contrast to pyramidal neurons of the hippocampus, where NPY exerts its effects presynaptically through NPY Y2 receptors (Colmers et al., 1991), our data indicate that both presynaptic and postsynaptic NPY receptors participate in the SCN and surrounding hypothalamus, via Y1, Y2, and perhaps additional Y-type receptors. NPY actions have been divided into two groups based on similarity to Y1- and Y2-like responses (Grundemar et al., 1993). Recent cloning studies, however, have revealed novel NPY Y4 and two Y5 receptors that have some pharmacological similarities to Y1 and Y2 receptors (Bardt et al., 1995; Gerald et al., 1996; Weinberg et al., 1996). These recently isolated receptors are expressed in the hypothalamus, including the SCN. Thus, some of the physiological responses to NPY described in the present paper may be mediated by these NPY receptors for which subtype-selective agonists are not yet available. The heterogeneity of NPY receptor expression presynaptically and postsynaptically may, in part, explain why some neurons show $\mathrm{LTD}_{\mathrm{Ca}}$, whereas other neurons show only transient depressions. Another factor that may explain why some neurons show $\mathrm{LTD}_{\mathrm{Ca}}$ and others show only a transient response to NPY may relate to the different ionotropic and metabotropic glutamate receptors expressed by subsets of these neurons (van den Pol, 1994; van den Pol et al., 1994). In the case of SCN neurons, different circadian phases of neurons in the same culture may contribute to the response heterogeneity.

\section{LTD in hypothalamic neurons}

Our experiments support the hypothesis that NPY requires the simultaneous release of glutamate for the generation of $\mathrm{LTD}_{\mathrm{Ca}}$, and suggest that NPY binding to its receptor for an extended period is not the cause of the long-lasting effect. The LTD effects are specific to NPY, because parallel experiments with the modulator adenosine showed only short-term reductions of glutamatemediated excitatory activity (Obrietan et al., 1995). We showed that the NMDA receptor is not necessary for the $\mathrm{LTD}_{\mathrm{Ca}}$; therefore, AMPA/kainate or metabotropic glutamate receptors are sufficient to achieve $\mathrm{LTD}_{\mathrm{Ca}}$ in combination with NPY stimulation in hypothalamic neurons. Furthermore, because we found little LTD $_{\mathrm{Ca}}$ with experiments in which we focused on postsynaptic 
responses to glutamate + NPY, the presynaptic axon may be critical for $\operatorname{LTD}_{\mathrm{Ca}}$.

NPY reduced the frequency of mEPSCs in the presence of TTX. Because TTX effectively isolated the axon terminals from their parent perikarya, any NPY actions on the cell body would not be expected to influence the cell's axon terminals or transmitter release. These data support the hypothesis that NPY can act at a presynaptic site on glutamate-secreting axons to reduce transmitter release in both SCN area cultures and SCN slices. This is consistent with previous observations that NPY acts on presynaptic axons in several brain areas (Colmers et al., 1991; Bleakman et al., 1992, 1993) and in peripheral neurons (Walker et al., 1988). An extended reduction of the mEPSC frequency was found with NPY application in some cells even under conditions of relatively low activity typically found in the presence of TTX. The longlasting effect of NPY on $\mathrm{Ca}^{2+}$ and action potentials, therefore, may depend on local microsignaling or feedback at the synaptic level between the excitatory presynaptic axon and the postsynaptic cell. Another consideration is that the reduction of the dynamic electrical activity and cytosolic $\mathrm{Ca}^{2+}$ levels, at least in part, may be dependent on cellular feedback in a network of synaptically coupled neurons, and may require a combination of presynaptic and postsynaptic NPY actions at glutamatergic synapses. A final possibility that merits exploration is that the presynaptic axons may bear glutamate receptors, and these need to be activated for NPY to evoke a maximal effect.

NPY exerts a depressing action on developing GABAergic neurons that is not dependent on coactivation of GABAergic axons (Obrietan and van den Pol, 1996). In contrast, in the present paper we demonstrate that robust LTD of excitatory activity, membrane potential, and cytoplasmic $\mathrm{Ca}^{2+}$ requires the coincident release of glutamate and activation of NPY receptors. The importance of glutamate may be to increase transmitter release, and NPY may act to induce postsynaptic $\mathrm{LTD}_{\mathrm{Ca}}$ by reducing transmitter release from active presynaptic axons. Because we found little latent effect of NPY on LTD $_{\mathrm{Ca}}$ if administered in the transient absence of glutamate activity, NPY may be more effective on active glutamate-secreting axons than on inactive ones in mediating $\mathrm{LTD}_{\mathrm{Ca}}$. The long-lasting actions of NPY may be state dependent, requiring the initial glutamate-mediated activation or elevation of some substrate, perhaps $\mathrm{Ca}^{2+}$. Previous work has suggested that an increase in $\mathrm{Ca}^{2+}$ may be necessary for LTD in a different model (Christofi et al., 1993). This is consistent with our finding that at the time of induction of $\mathrm{LTD}_{\mathrm{Ca}}$, cytosolic $\mathrm{Ca}^{2+}$ was raised by glutamate. Our data are unique in showing $\mathrm{LTD}_{\mathrm{Ca}}$ in these neurons.

An extended depression of intracellular $\mathrm{Ca}^{2+}$ would have the capacity to alter many aspects of neuronal function, including transmitter release and electrical activity, $\mathrm{Ca}^{2+}$ gated ion channels, $\mathrm{Ca}^{2+}$ binding proteins, and $\mathrm{Ca}^{2+}$ modulated gene expression. This extended change in the behavioral state of a neuron would have a significant influence on its functional output, and may represent a cellular substrate for the long-term effects of NPY on phase shifts in circadian rhythms controlled by the suprachiasmatic nucleus. Similar long-term changes in cellular behavior in the form of depression or potentiation may explain other paradigms of phase shifts of the circadian clock involving other peptides that may modulate glutamate activity.

\section{Functional considerations}

A long-term depression in cytosolic $\mathrm{Ca}^{2+}$, hypothetically, may be a cellular substrate in SCN neurons for NPY-induced phase shifts
(Albers and Ferris, 1984; Medanic and Gillette, 1993; Huhman and Albers, 1994) in circadian rhythms. A decrease in intracellular $\mathrm{Ca}^{2+}$ would have widespread effects on cellular function and transmitter release. In addition to its long-term effects on the circadian clock, NPY application also causes an extended bout of vigorous feeding that may last hours (Stanley and Leibowitz, 1985) and long-term alterations in the timing and release of gonadal hormones (McDonald et al., 1985, 1989). The longlasting depression of $\mathrm{Ca}^{2+}$ responses generated by NPY in cultured mediobasal hypothalamic neurons was similar to that of selective cultures of the suprachiasmatic nucleus, suggesting that NPY-mediated LTD could be involved in a number of hypothalamic homeostatic functions requiring long lasting changes in the activity of neurons.

Hypothalamic regulatory mechanisms involved in caloric maintenance, hormone control, and circadian time keeping depend on comparisons among different internal states over time, and that requires some form of long-term information processing of afferent signaling and cellular memory. Taking together the findings that glutamate appears to be the primary fast excitatory transmitter in the hypothalamus (van den Pol et al., 1990), that NPYcontaining terminals are found throughout the hypothalamus (Chronwall et al., 1985) and that the majority of hypothalamic neurons respond physiologically to NPY (present paper), then NPY-mediated LTD via a mechanism involving presynaptic modulation of glutamate transmission merits additional exploration as to whether it may explain other long-term effects of NPY on hypothalamic homeostatic regulation.

\section{REFERENCES}

Albers HE, Ferris C (1984) Neuropeptide Y: role in light-dark cycle entrainment of hamster circadian rhythms. Neurosci Lett 50:163-168.

Bardt JA, Walker MW, Branchek TA, Weinshank RL (1995) Cloning and functional expression of a human Y4 subtype receptor for pancreatic polypeptide, neuropeptide Y, and peptide YY. J Biol Chem 270:2676226765.

Bleakman D, Harrison N, Colmers WF, Miller RJ (1992) Investigation into neuropeptide $\mathrm{Y}$-mediated presynaptic inhibition in cultured hippocampal neurones of the rat. Br J Pharmacol 107:334-340.

Bleakman D, Miller RJ, Colmers WF (1993) Actions of neuropeptide Y on the electrophysiological properties of nerve cells. In: The biology of neuropeptide Y and related peptides (Colmers WF, Wahlestedt C, eds), pp 241-272. Totowa, NJ: Humana.

Bolshakov VW, Siegelbaum SA (1994) Postsynaptic induction and presynaptic expression of hippocampal long-term depression. Science 264:1148-1152.

Broome M, Hokfelt T, Terenius L (1985) Peptide YY (PYY)immunoreactive neurons in the lower brain stem and spinal cord of rat. Acta Physiol Scand 125:349-352.

Cahill GM, Menaker M (1989) Effects of excitatory amino acid receptor antagonists and agonists on suprachiasmatic nucleus responses to retinohypothalamic tract volleys. Brain Res 479:76-82.

Card J, Moore R (1989) Organization of lateral geniculate-hypothalamic connections in the rat. J Comp Neurol 284:135-147.

Christofi G, Nowicky AV, Bolsover SR, Bindman LJ (1993) The postsynaptic induction of nonassociative long-term depression of excitatory synaptic transmission in rat hippocampal slices. $\mathrm{J}$ Neurophysiol 69:219-229.

Chronwall B, DiMaggio D, Massari V, Pickel V, Ruggiero D, O’Donohue $\mathrm{T}$ (1985) The anatomy of neuropeptide Y containing neurons in the rat brain. Neuroscience 15:1159-1181.

Colmers WF, Klapstein GJ, Fournier A, St.Pierre S, Treherne KA (1991) Presynaptic inhibition by neuropeptide $\mathrm{Y}$ in rat hippocampal slice in vitro is mediated by a Y2 receptor. Br J Pharmacol 102:41-44.

Colwell CW, Foster RG, Menaker M (1991) NMDA receptor antagonists block the effects of light on circadian behavior in mouse. Brain Res 554:105-110. 
Dudek S, Bear M (1992) Homosynaptic long-term depression in area CA1 of hippocampus and effects of $N$-methyl-D-aspartate receptor blockade. Proc Natl Acad Sci USA 89:4363-4367.

Forscher P, Kaczmarek L, Buchanan J, Smith S (1987) Cyclic AMP induces changes in distribution and transport of organelles within growth cones of Aplysia bag cell neurons. J Neurosci 7:3600-3611.

Foucart S, Bleakman D, Bindokas VP, Miller RJ (1993) Neuropeptide Y and pancreatic polypeptide reduce calcium currents in acutely dissociated neurons from adult rat superior cervical ganglia. J Pharmacol Exp Ther 265:903-909.

Gerald C, Walker MW, Criscione L, Gustafson EL, Batzl-Hartmann C, Smith KE, Vaysse P, Durkin MM, Laz TM, Linemeyer DL, Schaffhauser AO, Whitebread S, Hofbauer KG, Tabe RI, Branchek TA, Weinshank RL (1996) A receptor subtype involved in nueropeptide Y-induced food intake. Nature 382:168-171.

Grundemar L, Sheikh SP, Wahlestedt C (1993) Characterization of receptor types for neuropeptide $\mathrm{Y}$ and relative peptides. In: The biology of neuropeptide Y and related peptides (Colmers WF, Wahlestedt C, eds), pp 197-239. Totowa, NJ: Humana.

Grynkiewicz G, Poenie M, Tsien R (1985) A new generation of calcium indicators with greatly improved fluorescence properties. J Biol Chem 260:3440-3450.

Harrington ME, Rusak B (1986) Lesions of the thalamic intergeniculate leaflet alter hamster circadian rhythms. J Biol Rhythms 1:309-325.

Harrington ME, Nance DM, Rusak B (1985) Neuropeptide Y immunoreactivity in the hamster geniculo-suprachiasmatic tract. Brain Res Bull 15:465-472.

Huhman K, Albers HE (1994) Neuropeptide Y microinjected into the suprachiasmatic region phase shifts circadian rhythms in constant darkness. Peptides 8:1475-1478.

Johnson RF, Moore RY, Morin LP (1989) Lateral geniculate lesions alter circadian activity rhythms in the hamster. Brain Res Bull 22:411-422.

Kim Y, Dudek FE (1991) Intracellular electrophysiological study of suprachiasmatic nucleus neurones in rodents: excitatory synaptic mechanisms. J Physiol (Lond) 444:269-287.

Kombian SB, Colmers WF (1992) Neuropeptide Y selectively inhibits slow synaptic potentials in rat dorsal raphe nucleus in vitro by a presynaptic action. J Neurosci 12:1086-1093.

Lynch DR, Walker MW, Miller RJ, Snyder SH (1989) Neuropeptide $Y$ receptor binding sites in rat brain: differential autoradiographic localizations with iodine-125 labeled peptide YY and iodine-125 labeled neuropeptide Y imply receptor heterogeneity. J Neurosci 9:2607-2619.

McDonald JK, Lumpkin MD, DePaolo LV (1989) Neuropeptide-Y suppresses pulsatile secretion of luteinizing hormone in ovariectomized rats: possible site of action. Endocrinology 125:186-191.

McDonald JK, Lumpkin MD, Samson WK, McCann SM (1985) Neuropeptide $\mathrm{Y}$ affects secretion of luteinizing hormone and growth hormone in ovariectomized rats. Proc Natl Acad Sci USA $82: 561-564$.

McQuiston AR, Petrozzino JJ, Connor JA, Colmers WF (1996) Neuropeptide $\mathrm{Y} 1$ receptors inhibit $\mathrm{N}$-type calcium currents and reduce transient calcium increases in rat dentate granule cells. J Neurosci $16: 1422-1429$.

Medanic M, Gillette M (1993) Suprachiasmatic circadian pacemaker of rat shows two windows of sensitivity to neuropeptide $\mathrm{Y}$ in vitro. Brain Res 620:281-286.

Meijer JH, Van Der Zee EA, Dietz M (1988) Glutamate phase shifts circadian activity rhythms in hamsters. Neurosci Lett 86:177-183.

Mulkey R, Malenka R (1992) Mechanisms underlying induction of homosynaptic long-term depression in area CA1 of the hippocampus. Neuron 9:967-975.

Nelson DE, Takahashi JS (1991) Sensitivity and integration in a visual pathway for circadian entrainment in the hamster (Mesocricetus auratus). J Physiol (Lond) 439:115-146.
Obrietan K, van den Pol AN (1995) Calcium hyperexcitability in neurons cultured with glutamate receptor blockade. J Neurophysiol 73:1524-1536.

Obrietan K, van den Pol AN (1996) NPY depresses GABA-mediated calcium transients in developing SCN neurons: a novel form of calcium long term depression. J Neurosci 16:3521-3533.

Obrietan K, Belousov A, Heller C, van den Pol AN (1995) Adenosine pre- and postsynaptic modulation of glutamate-dependent calcium activity in hypothalamic neurons. J Neurophysiol 74:2150-2160.

Rusak B, Meijer JH, Harrington ME (1989) Hamster circadian rhythms are phase-shifted by electrical stimulation of the geniculo-hypothalamic tract. Brain Res 498:283-291.

Stanley B, Leibowitz S (1985) Neuropeptide Y injected in the paraventricular hypothalamus: a powerful stimulant of feeding behavior. Proc Natl Acad Sci USA 82:3940-3943.

Tatemoto K, Carlquist M, Mutt V (1982) Neuropeptide Y: a novel brain peptide with structural similarities to peptide $\mathrm{YY}$ and pancreatic polypeptide. Nature 296:659-660.

Thiels E, Barrionuevo G, Berger TW (1994) Excitatory stimulation during postsynaptic inhibition induces long-term depression in hippocampus in vivo. J Neurophysiol 72:3009-3016.

Thompson RF (1967) Foundations of physiological psychology. New York: Harper \& Row.

Toth PT, Bindokas VP, Bleakman D, Colmers WF, Miller RJ (1993) Mechanism of presynaptic inhibition by neuropeptide $\mathrm{Y}$ at sympathetic nerve terminals. Nature 364:635-639.

Tsien RW (1987) Calcium current in heart cells and neurons. In: Neuromodulation (Kaczmarek LK, Levitan IB, eds), pp 206-242. Oxford: Oxford UP.

van den Pol AN (1994) Metabotropic glutamate receptor mGluR1 distribution and ultrastructural localization in hypothalamus. J Comp Neurol 349:615-632.

van den Pol AN, Dudek FE (1993) Cellular communication in the circadian clock, the suprachiasmatic nucleus. Neuroscience 56:793-811.

van den Pol AN, Trombley PQ (1993) Glutamate neurons in hypothalamus regulate excitatory transmission. J Neurosci 13:2829-2836.

van den Pol AN, Wuarin JP, Dudek FE (1990) Glutamate, the dominant excitatory transmitter in neuroendocrine regulation. Science 250:1276-1278.

van den Pol AN, Hermans-Borgmeyer I, Hofer M, Ghosh P, Heinemann S (1994) Ionotropic glutamate-receptor gene expression in hypothalamus: localization of AMPA, kainate, and NMDA receptor RNA with in situ hybridization. J Comp Neurol 343:428-444.

van den Pol AN, Obrietan K, Belousov A (1995a) NPY modulation of hypothalamic glutamate transmission. Soc Neurosci Abstr 21:430.

van den Pol AN, Obrietan K, Cao V, Trombley PQ (1995b) Embryonic hypothalamic expression of functional glutamate receptors. Neuroscience 67:419-439.

Walker MW, Miller RJ (1988) ${ }^{125}$ I-neuropeptide Y and ${ }^{125}$ I-peptide YY bind to multiple receptor sites in rat brain. Mol Pharmacol 34:779-792.

Walker MW, Ewald D, Perney T, Miller R (1988) Neuropeptide Y modulates neurotransmitter release and $\mathrm{Ca}^{2+}$ currents in rat sensory neurons. J Neurosci 8:2438-2446.

Wahlestedt C, Grundemar L, Hakanson R, Heilig M, Shen GH, Zukowska-Grojec Z, Reis DJ (1990) Neuropeptide Y receptor subtypes, Y1 and Y2. Ann NY Acad Sci 611:7-26.

Wahlestedt C, Regunathan S, Reis D (1992) Identification of cultured cells selectively expressing Y1-, Y2-, or Y3-type receptors for neuropeptide Y/peptide YY. Life Sci 50:PL7-P12.

Weinberg DH, Sirinathsinghji DJS, Tan CT, Shiao LL, Morin N, Rigby MR, Heavens RH, Rapoport DR, Bayne ML, Cascieri MA, Strader CD, Linemeyer DL, MacNeil DJ (1996) Cloning and expression of a novel neuropeptide Y receptor. J Biol Chem 271:16435-16438.

Yang X-D, Connor JA, Faber DS (1994) Weak excitation and simultaneous inhibition induce long-term depression in hippocampal CA1 neurons. J Neurophysiol 71:1586-1590. 